\title{
Forest ecosystem-service transitions: the ecological dimensions of the forest transition
}

\author{
$\underline{\text { Sarah Jane Wilson }}^{1,2}, \underline{\text { John Schelhas }}^{3}$, Ricardo Grau $^{4,5}, \underline{\text { A. Sofia Nanni }}^{6}$ and Sean Sloan $^{7}$
}

\begin{abstract}
New forests are expanding around the world. In many regions, regrowth rates are surpassing deforestation rates, resulting in "forest transitions," or net gains in forest cover. Typically measured only in terms of aggregate"forest cover" change, these new forests are ecologically distinct from each other and from those originally cleared. We ask, what are the ecological attributes, goods, and services we might expect from different pathways of forest recovery? To address this question, we proposed a typology of forest transitions that reflects both their social drivers and ecological outcomes: tree plantation, spontaneous regeneration, and agroforestry transitions. Using case studies, we illustrate how the ecological outcomes of each transition type differ and change over time. We mapped the global distribution of forest-transition types to identify global epicenters of each, and found that spontaneous transitions are most common globally, especially in Latin America; agroforestry transitions predominate in Europe and Central America; and plantation transitions occur in parts of Europe and Asia. We proposed a conceptual framework to understand and compare the ecological services arising from different types of forest transitions over time: forest ecosystem-service transition curves. This framework illustrates that carbon sequestration tends to be comparatively lower in agroforestry transitions, and biodiversity recovery is lower in industrial plantations. Spontaneously regenerating forests tend to have relatively high biodiversity and biomass but provide fewer provisioning and economically valuable services. This framework captures the dynamism that we observe in forest transitions, thus illustrating that different social drivers produce different types of ecosystem-service transitions, and that as secondary forests grow, these services will change over time at rates that differ among transition types. Ultimately, this framework can guide future research, describe actual and potential changes in ecosystem services associated with different types of transitions, and promote management plans that incorporate forest cover changes with the services and benefits they provide.
\end{abstract}

Key Words: biodiversity; carbon; ecosystem services; forest conservation; forest cover change; forest transition; land use change; plantations; secondary forest

\section{INTRODUCTION}

Even as forest area continues to decline globally, forest cover is increasing in many regions as the area of "new forests" (i.e., secondary forests, plantations, and other woody vegetation) increases (Sloan and Sayer 2015, Rudel et al. 2016). Over the past two centuries, notable forest transitions, in which a country or region moves from losing to gaining net forest cover (Fig. 1A), occurred in Western Europe and the United States (Mather 1992, Rudel et al. 2005). Driven by industrialization, agricultural intensification, and rural-to-urban migration, forest cover increased through both spontaneous forest succession on abandoned agricultural lands and tree plantations (Mather 1992, Rudel et al. 2005, Meyfroidt and Lambin 2011). More recently, forests have begun to return in many tropical countries, suggesting incipient tropical forest transitions (Rudel et al. 2002, Sloan 2008, Vaca et al. 2012, Aide et al. 2013, Sloan and Sayer 2015). These new forests are often ecologically distinct from those originally cleared (Dent and Wright 2009, Meyfroidt and Lambin 2011, Redo et al. 2012, Chazdon et al. 2016), and the ecological consequences of these tropical transitions are still poorly understood. The scale, speed, and ecological nature of nascent tropical forest transitions raise important questions about the ecological and environmental benefits they will ultimately provide.
The forest transition literature measures primarily changes in undifferentiated forest area without considering the ecological characteristics of the forest (Mather 1992, Rudel et al. 2005) (Fig. 1). But from ecological and social perspectives, aggregate area of "forest" (or "tree") cover provides a poor metric of the social and environmental benefits from expanding new forests, both in the short and long term (Chazdon et al. 2016).

Rudel et al. (2005) and Lambin and Meyfroidt (2010) identified several pathways of socio-agrarian change that can lead to forest transitions. Different pathways and drivers of forest recovery can produce different types and distributions of forest cover, which possess different ecological characteristics (e.g., biodiversity, biomass, structure, and proportions of native and non-native species) (Holl et al. 2000, Chazdon 2003, 2014, Dent and Wright 2009, Wilson and Rhemtulla 2016), geographic characteristics (e.g., regrowth on steep slopes or plantations near roads) (Dent and Wright 2009, Redo et al. 2012, Nanni and Grau 2014, Angonese and Grau 2014, Sloan 2016), and landscape attributes (e.g., connectivity, spatial relationships among secondary and remnant primary forest, habitat corridors) (Thomlinson et al. 1996, Hecht and Saatchi 2007, Angonese and Grau 2014) (Fig. 2). Different ecological attributes, configurations, and trajectories of new forests in turn produce different suites of ecosystem services (Chazdon 2008, Grau et

\footnotetext{
${ }^{1}$ School of Natural Resources and Environment, University of Michigan, ${ }^{2}$ PARTNERS Reforestation Network, ${ }^{3}$ U.S. Forest Service, Southern Research Station, ${ }^{4}$ Instituto de Ecología Regional, ${ }^{5}$ Universidad Nacional de Tucumán-CONICET, ${ }^{6}$ Instituto de Ecología Regional and Consejo Nacional de Investigaciones Científicas y Técnicas (CONICET), Universidad Nacional de Tucumán, ${ }^{7}$ College of Marine and Environmental Science Center for Tropical Environmental and Sustainability Science James Cook University, Cairns, Australia
} 
al. 2008, Locatelli et al. 2015), which change over the trajectory of the forest transition. Although the forest transition literature has identified different pathways of social change that can produce forest transitions (Rudel et al. 2005, Lambin and Meyfroidt 2010), and the ecological literature has established that recovering forests provide a variety of ecosystem services that differ between forest types (Brown and Lugo 1990, Chazdon 2008, 2014, Dent and Wright 2009), to date these fields have not been systematically integrated to examine the ecological consequences of forest transitions over time.

Fig. 1. The forest transition. (A) The classic forest-transition curve, depicting a decrease in forest area over a given geographical area (continental, national, or regional), followed by an increase as forests return. (B) The distinction between primary and secondary forests, and the relative amounts of each at the forest-area inflection point. Note that point A represents a transition with a relatively high proportion of primary forest remaining, whereas at point $\mathrm{B}$, most forests on the landscape are secondary.
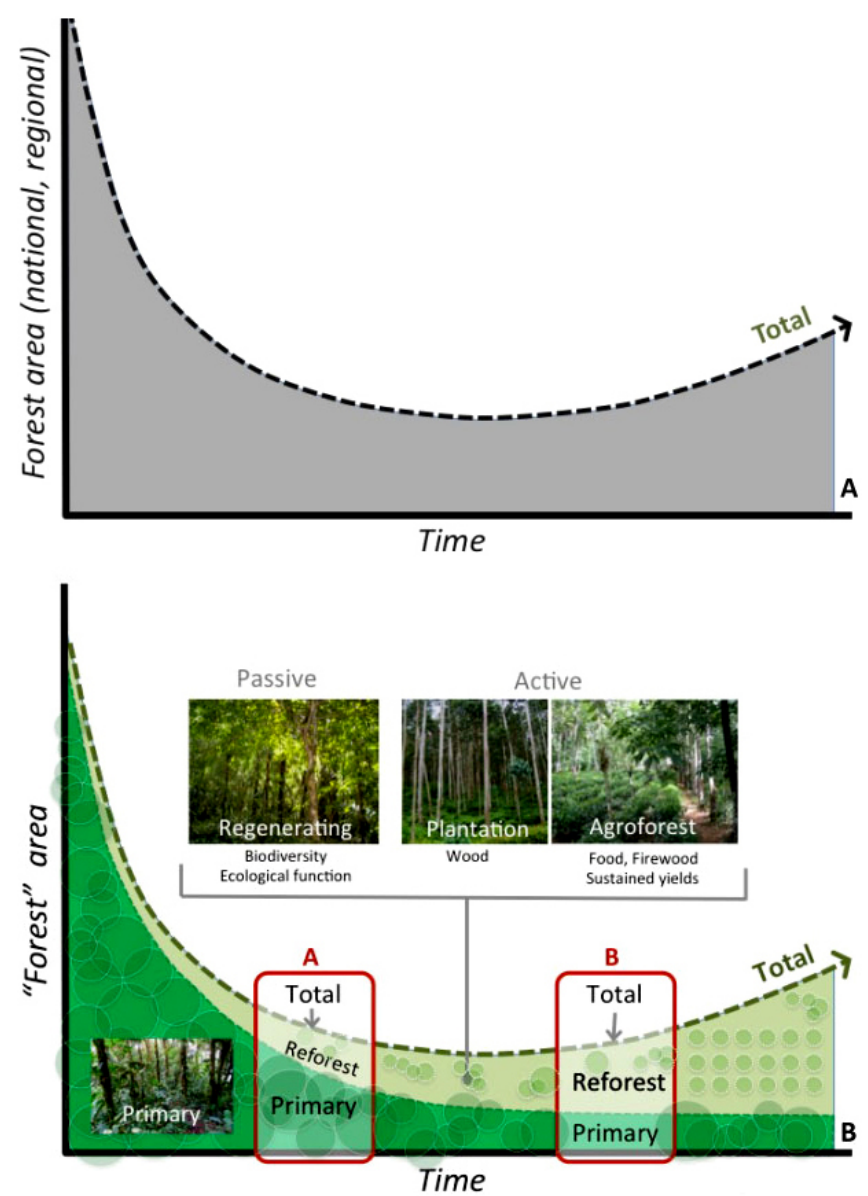

We examine how variations in the type and drivers of a given forest transition correspond with ecological variations in forests and forest services over time. We address three key questions: (1) What ecological attributes, goods, and services might we expect from different pathways of forest recovery? (2) How do the ecological characteristics of forests resulting from different forest transitions differ from the forests that previously existed, as well as from each other? (3) How common are the different forms of reforestation underlying our forest transition types globally, and how are they and the forests and services associated with them geographically distributed?

We propose a conceptual framework: "the forest ecosystemservice transition." This framework describes the ecological attributes, goods, and services arising from different forest transition pathways, how these change over the trajectory of a forest transition, and how they differ from pre-existing forests. We support this concept with current literature on the ecosystem services arising from different types of secondary forests, and with case studies of the drivers and services arising from transitions in different ecological and social contexts. To operationalize this concept, we use existing data sets to estimate the global distribution of different forest transition types and their respective suites of ecosystem services.

Our paper is structured as follows. The first section defines a typology of forest transitions relevant to ecological outcomes by summarizing the forest transition literature. The second section draws on the ecological literature to highlight the ecological characteristics of new forests and their associated ecosystem services. In the third section, we present four case studies of subtropical and tropical forest transitions to provide examples of different ecosystem-service transitions, how they arise, and how they change over time. In the fourth section, we synthesize the previous sections and present conceptual "forest ecosystemservice transition curves" to illustrate how the ecosystem services arising from different forest transition types converge and diverge over time. In the fifth section, we estimate the prevalence of different forest transition pathways globally and apply our ecosystem-service transition curves to describe global patterns in the ecosystem services that may result from different pathways of recovery.

By incorporating a nuanced ecological perspective into a largely social science-based forest-transition theory, our synthesis provides a framework for understanding and anticipating the ecosystem goods and services that new forests can provide over time. While at present, data are not sufficient to test our framework, we believe that our conceptual framework will help guide future research and make the forest transition theory more useful to policy and planning.

\section{FOREST TRANSITION TYPOLOGIES}

Forest transitions are driven by changes in socio-economic conditions and cultural perceptions of remnant forests, often in concert (Mather 1992). Rudel et al. (2005) identified two main pathways by which forest transitions occur: the urban-economic development pathway, where rural to urban migration creates opportunities for new forests to spontaneously regenerate on abandoned, marginal agricultural land, and the forest scarcity pathway, where declines in forest coupled with demand for forests goods and services induce landowners and governments to plant trees. Lambin and Meyfroidt (2010) expanded this dichotomy to incorporate three contemporary forest transition pathways emerging in tropical areas: a smallholder agroforestry pathway, where smallholders plant trees to intensify land use, increase productivity, and stabilize crop yields (Rudel 2005, 2009, Tiffen 
Fig. 2. The three forest transition pathways, their drivers, and their relative ecological outcomes. Note: The final column represents the potential amount of each service that would be expected to return during a transition, relative to the other transition types. (NTFP: nontimber forest product)

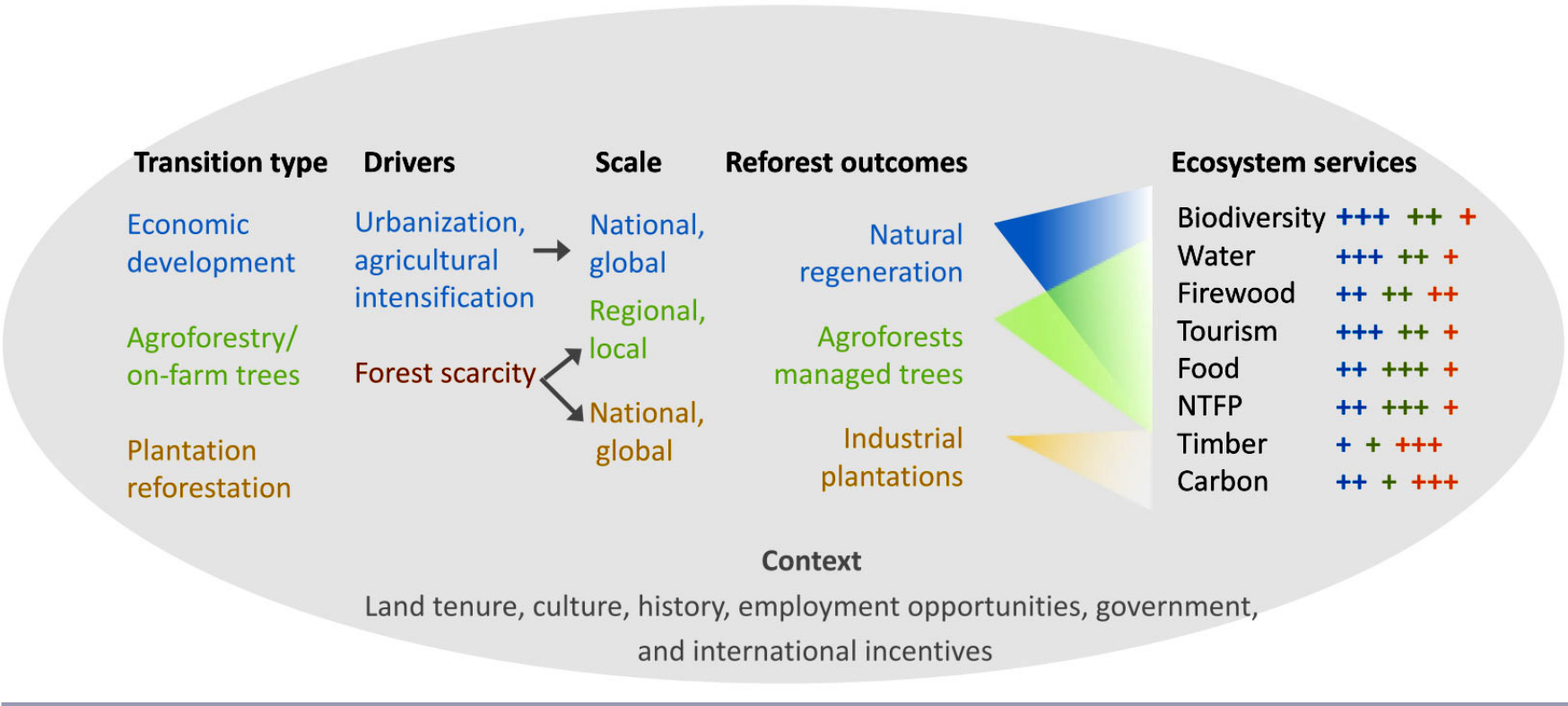

et al. 1994); a globalization pathway — a contemporary urbaneconomic development pathway in which rural poor seek employment and send back remittances from outside their country, potentially reducing local agricultural activities (Aide and Grau 2004, Hecht et al. 2006); and a state forest policy pathway, in which "strong states" seeking to fulfill economic and political agendas formalize land titling and conserve and plant forests to arrest soil degradation, protect watersheds, or increase the supply of forest products (Mather 2007, Meyfroidt and Lambin 2008).

Local contexts and cultures create variations in the aforementioned pathways, and as a result, the outcomes are not easily quantified. Culture clearly influences the nature of new forests and inflection points, and whether there is a forest transition at all. Despite the importance of culture-Mather (1992) suggested that changing environmental values, social movements, and policies can also drive increases in forest cover —neither Meyfroidt and Lambin (2008) nor Rudel et al. (2005) emphasize cultural drivers. But during the forest transitions observed in the United States, western Europe, and parts of Latin America, forests have also returned as they have become more valuable for cultural reasons. Cultural values, discourse, and religion may deem forests important for aesthetics, recreation, and spiritual appreciation of biodiversity and nature generally, and thus contribute to the pathways of forest recovery described by Lambin and Meyfroidt (2010). Globalization transitions have occurred as conservation ideologies have spread (Brechin and Kempton 1994, Schelhas and Pfeffer 2008); forests have returned when communities protect them for spiritual reasons, as has occurred in Himalayan forests (Lambin and Meyfroidt 2010), and a recent forest landscape restoration "movement" is well poised to produce regional transitions in the coming decade (Kull et al. 2007, Schelhas and Pfeffer 2008, Lambin and Meyfroidt 2010).
Cultural transitions, which occur even in the poorest counties (such as Nepal), partially counter the idea that forest transitions are driven mostly by economic factors and thus occur mainly in wealthier, "developed" countries (Lambin and Meyfroidt 2010).

We examine the ecological outcomes of three different forest transition pathways: economic growth, industrial plantation reforestation, and smallholder agroforestry/on-farm trees. This typology integrates the diverse social drivers of the aforementioned pathways into a typology in which different pathways are associated with distinct ecological outcomes (Fig. 1, Fig. 2). Our typology reflects the economic growth versus forest scarcity dichotomy described by Rudel et al. (2005), but it also splits their forest scarcity pathway (as per Lambin and Meyfroidt 2010) to distinguish industrial plantation reforestation (large, commercial tree plantations, generally implemented by strong states and commercial forestry interests) from smallholder agroforestry intensification (smaller scale tree planting and assisted regeneration, generally undertaken to provide local forest goods and services). We also consider the effect of cultural factors on landholders' actions in situations of both forest scarcity and economic growth (Mather 1992, Robbins and Fraser 2003, Redman and Foster 2008) through our four case studies. We elaborate on each pathway of our social-ecological typology to illustrate how each produces different ecosystem goods and services (Fig. 2).

The economic development pathway can occur when countries or regions urbanize, agriculture modernizes, and opportunities for work and education in cities draw people off the land. As a result of both a reduction in on-farm labor capacity and the increasing availability of labor-reducing technology for agricultural production, farmers mechanize and intensify production on flatter, more fertile land, and abandon marginal 
lands (Rudel et al. 2005). In some cases, forests have regenerated spontaneously on these lands (Bentley 1989, Aide and Grau 2004, Daniels 2010). Similarly, forests have regenerated when economic collapse and withdrawal of government subsidies induced farmers to abandon agricultural land, as occurred in Cuba and Eastern Europe after the fall of the Soviet Union (Kuemmerle et al. 2011, Alvarez et al. 2013).

The type of forests produced by economic-driven transitions varies with context and the surrounding forest landscape. Vegetation regenerating on abandoned land ranges from lush, productive forests where land remains fertile and seed sources are nearby (Thomlinson et al. 1996, Chazdon 2003, 2008) to grasses and shrubland where land is too degraded for regrowth without intervention (Holl et al. 2000, Wilson and Rhemtulla 2016). Regrowth in areas surrounded by intact forest tends to have more native species, higher diversity, and spatial connectivity than that in extensively cleared areas (Holl et al. 2000, Sloan et al. 2015). In peri-urban areas, new forests produced by economic growth (e.g., managed parks, plantations) sometimes resemble the "simplified" forests produced by forest scarcity transitions, and often contain relatively high proportions of non-native species. These forests can also be ephemeral, subject to clearing if land values rise (Grau et al. 2003, Padoch 2007, Padoch et al. 2008, Lugo 2009, Gutierrez and Grau 2014). Forest species composition and integrity will vary depending on whether landholders abandon lands outright or maintain a reduced or iterant presence in the landscape (Hecht and Saatchi 2007) and whether migration is long distance and thus more "permanent" or local/cyclical (Waters 1997, Schmook and Radel 2008).

If forests are perceived as scarce at the country, regional, or local/ household level, forest cover may expand as people intentionally plant trees (Mather 1992, Rudel et al. 2005, Rudel 2009). Governments may subsidize plantations to produce forest goods and commodities (e.g., timber, palm oil) or to stabilize land in regions degraded by deforestation (Mather 1992, Rudel et al. 2005, Sloan 2016), thereby potentially producing industrial plantation transitions. These forests differ from natural forests but are nevertheless included in many national and global estimates of tree and forest cover (FAO 2015, Chazdon et al. 2016). State-driven reforestation is mediated by social and cultural processes and so does not necessarily reflect "objective" forest scarcity. It can also occur where prices signal perceived scarcity (as in Indonesia) or a lack of essential forest services (as in Vietnam) (Mather 2007). Similarly, at the regional level, communities and municipalities may plant trees to protect or restore ecosystem services, such as water or nontimber forest products (NTFPs) (Wilson 2015), or to supply forest products for increasing demand (e.g., fuel for the steel industry in Brazil) (Sonter et al. 2014). At both national and regional scales, the distribution of "new forests" in scarcity-driven transitions is heavily influenced by land values, and is sometimes confined to unproductive uplands that are relinquished or disused by other land users (Grau et al. 2003, Laclau 2003, Padoch et al. 2008), although market signals or local values may occasionally invert these expected "core-periphery" patterns (Foster and Rosenzweig 2003, Sloan 2016).

On a local scale, the scarcity of forest products (i.e., firewood, timber, food crops) and services (i.e., soil maintenance, erosion control, shade) can drive smallholders to plant or protect forest cover in and around farms to enhance household production and resilience, thereby producing smallholder agroforestry transitions (Reij et al. 2005, Reij 2006, Rudel 2009, Wilson 2015). Although practiced at small scales, widespread agroforestry intensification has produced significant national-scale gains in forest cover in the African context (Reij 2006). Compared to other forms of reforestation, agroforestry tends to be labor intensive and often highly utilitarian; thus, agroforests often correlate positively with rural population density (Rudel et al. 2005, Rudel 2009).

Regardless of scale, scarcity-driven transitions (both industrial plantation and smallholder agroforestry) will usually produce human-created forests (plantations, agroforests) with different social-ecological properties from the forests that were originally cleared (Fig. 1, Fig. 2). In particular, these utilitarian forests often have a simpler structure (tree size, age, species composition) than primary forests, and contain species with high commercial value or multiple uses (Wilson and Rhemtulla 2016). This ecological simplification is generally greater for industrial plantations than for agroforests (Bhagwat et al. 2008, Chazdon et al. 2016).

Changes in culture and social processes shape the aforementioned pathways, and can also lead to forest regrowth. Forest cover may increase because people encourage or permit forests to return for recreation or spiritual reasons because they believe forests possess intrinsic value, or to conserve biodiversity. Cultural changes can be prompted by economic development (Stern 2004) combined with forest scarcity (Wilson 2015), as when, for example, a growing middle class desires forests for recreation and natural amenities (Locatelli et al. 2017). But cultural changes are also shaped and motivated by social movements and processes that operate across these paradigms. Changes in how people perceive or value forests may be realized far from their original source through globalization: the rise and global spread of environmentalism (Brechin and Kempton 1994, Schelhas and Pfeffer 2008); international initiatives (e.g., the Bonn Challenge, which aims to restore 150 million hectares of deforested land by 2020, and the UN Sustainable Development Goals) (Kull et al. 2007, Schelhas and Pfeffer 2008, Lambin and Meyfroidt 2010); tree planting cultures and associated organizations and campaigns (Brechin 1997, Cohen 2004); and social demand for forest-grown crops, such as shade coffee (Perfecto et al. 1996). Local, cultural-driven initiatives can also produce transitions when local communities install biodiverse, native forest restoration plantations (Diaz et al. 2009, Piotto et al. 2010, Potvin et al. 2011), as occurred during a forest-oriented "back to the land" sustainable production movement in Ecuador (Wilson 2015). Cultural shifts can therefore operate across other types of pathways, and produce a variety of different forest types in a range of different contexts.

\section{ECOLOGICAL OUTCOMES OF FOREST TRANSITIONS}

Forest transitions, like all land use and cover changes, have implications for biodiversity and ecosystem function. However, these are often poorly appreciated because the forest-transition literature addresses changes to overall forest cover, and ignores ecologically important characteristics such as forest age, species composition, vertical structure, or all but the most severe levels of degradation (Lund 2009, FAO 2011, Hansen et al. 2014, Putz and Romero 2014, Tropek et al. 2014, Chazdon et al. 2016, but see Kauppi et al. 2006). Different types and ages of forests are 
known to support different types of species, biodiversity, biomass, and other structural and functional features (Bhagwat et al. 2008, Dent and Wright 2009, Klanderud et al. 2010, Chai and Tanner 2011, Martin et al. 2013, Putz and Romero 2014). However, forest transition theory fails to systematically account for biophysical differences in forest types and dynamics, including the amount and distribution of primary forest remaining at the inflection point, the rate and extent of forest recovery, and the types of resulting new forests (Perz 2007). The following discusses such points in relation to the ecological implications of a forest transition.

\section{Forest cover inflection points and primary forest cover}

In many regions around the world, more than half of extant forest cover is secondary (including naturally regenerating and plantations) (FAO 2015). New forests possess different ecological and social attributes from primary forests, and from each other, and ultimately provide different services and goods to both local and global users (Pascarella et al. 2000, Kanowiski et al. 2005, Bhagwat et al. 2008). The ecological implications of forest transitions vary according to the degree to which primary forests were cleared or degraded, and to which deforestation and reforestation occur simultaneously. Areas of expanding and retracting forest cover also often differ in geographic location (i.e., deforestation in the lowlands and reforestation in highlands), which will affect the services provided after a transition, especially in regions with steep topographic gradients (Redo et al. 2012, Aide et al. 2013, Nanni and Grau 2014). If primary forests continue to be cleared as forests regrow, or if inflection points occur at low levels of forest cover, even large increases in forest cover may fail to sustain forest ecological value (such as native species biodiversity) compared to transitions that occur with more remaining primary forest cover (Mather 1992, Gibson et al. 2011, Dent and Wright 2009). Primary forests are important sources of native propagules for nearby secondary forests (Dent and Wright 2009, Holl et al. 2000, Chazdon 2014); without them, the biodiversity potential of secondary forests is greatly diminished (Gibson et al. 2011).

The extent to which primary forests are depleted prior to a forest transition is related partly to the drivers of the transition (Mather 1992) and the simultaneity of the drivers of deforestation and reforestation (Grainger 1995, Sloan 2008). Forest scarcity transitions are most likely when primary forests are depleted to critical levels, but can begin even as primary forests are being cleared (Grainger 1995, Mather 1992). In some cases, plantations replace primary forests (Rudel et al. 2016), as occurred with oil palm and acacia in Southeast Asia, which further degrades native forests (Chazdon et al. 2016). The extent of primary forest remaining at the time of a forest transition varied between countries in the historical European context, partially driven by demographic shifts, agricultural intensification, or other external economic forces (Mather 1992). National inflection points have occurred at increasingly greater levels of forest cover over the past two centuries (Rudel et al. 2005), possibly due to global cultural attitudes toward forest conservation, although the precise reasons are unknown (Rudel, personal communication).

\section{Ecosystem services from tropical secondary forests}

Tropical secondary forest can take decades or even centuries to attain the plant species diversity of primary forests (Lamb et al. 2005, Klanderud et al. 2010, Chazdon 2014). The ecological properties of the new forests diverge from each other and from primary forests in various ways depending on ongoing use and management, past land use, landscape attributes, and species available or used, factors which vary systematically among our three forest-transition types.

Spontaneously regenerating forests

Where environmental conditions allow, forests spontaneously regenerate when other land uses (e.g., agriculture, pasture) stop, which can occur when land is abandoned or intentionally protected (Chazdon 2014). In the forest transition literature, researchers often attribute spontaneous regeneration to shifts to more intensive farming practices, which lead farmers to abandon marginal land and concentrate farming in the most fertile and/or accessible areas, or to declines in agricultural activity following a decrease in rural populations (Mather 1992, Aide and Grau 2004, Rudel et al. 2005). But forests also sometimes fail to spontaneously regenerate. Less productive areas with long histories of land use and clearing are the least likely to recover unassisted (Aide et al. 2010, Mulligan 2010, Young 2011). Deforested areas dominated by non-native, sometimes invasive, fire-prone grasses and other competitive vegetation can also retard or preclude forest recovery (Aide et al. 2010).

Spontaneously regenerating forests often rapidly accumulate above-ground biomass, and sequester large amounts of carbon, although when both above-ground and soil carbon are considered, most will still contain less biomass than a mature forest even after 80 years (Martin et al. 2013, Chazdon 2014, Poorter et al. 2016). However, the diversity and composition of plant species in spontaneously regenerating forests often remains different from primary forests for decades to centuries (Lamb et al. 2005, Dent and Wright 2009, Klanderud et al. 2010, Chai and Tanner 2011, Martin et al. 2013). Forest plant species composition and diversity vary depending on duration and intensity of past land use, the amount of remnant primary forest, and the available species pool (which may include non-native tree propagules) (Uhl et al. 1988, Aide et al. 2000, Guariguata and Ostertag 2001, Chazdon et al. 2003, Foster et al. 2003, Styger et al. 2007, Cramer et al. 2008). Spontaneously regenerating forests are also a source of timber and nontimber products (e.g., food, medicines, and firewood for many local peoples) and often contain more culturally and economically "useful" species than do local primary forests (Kirby and Potvin 2007, Wilson and Rhemtulla 2016).

\section{Industrial plantations}

In the tropics, industrial plantations are one of the most common types of planted "forest," and are often monospecific stands of non-native species (such as teak, eucalyptus, pine, rubber, oil palm) (FAO 2010, Rudel 2009, Payn et al. 2015). Plantations of fast-growing trees can sequester large amounts of carbon at rates that are higher than natural secondary forests (Kraenzel et al. 2003). This carbon may remain sequestered if harvested wood is used for long-term construction and plantations are regenerated (Oliver et al. 2014), but plantation reforestation remains a relatively risky option for long-term carbon sequestration because of their vulnerability to pest outbreaks, wind, and fire, which release stored carbon to the atmosphere (Jactel et al. 2005, Abbas et al. 2016).

Plantation trees may be harvested in as few as 10 years, thereby quickly producing timber, fuel, or pulp, often at the expense of 
other ecosystem services. Some plantation forests house highly diverse plant communities in their understories (Lugo 1997), but some also emit toxins that prevent other trees from growing. Managers also often employ techniques to minimize the understory and natural tree recruitment. In general, plantations have much simpler structures and accommodate fewer animals and plants than do native forests (Healey and Gara 2003, Kanowiski et al. 2005).

Plantation trees often grow well in harsh conditions but can also degrade soils where, for example, fast-growing commercial species (such as teak) that inhibit understory growth are established in marginal areas (Healey and Gara 2003, Zhang et al. 2010). Depending on the environment and their situation in the landscape, plantations can enhance water resources and mitigate floods, but they may also consume large quantities of water, thereby reducing stream flow and groundwater recharge (O'Loughlin and Nambiar 2001, Jackson et al. 2005). The net effects of plantations on hydrological function are both unclear and context dependant.

\section{Agroforests and on-farm trees}

On-farm trees include agroforestry systems, household plantations (typically smaller and more diverse than industrial plantations), windbreaks, and orchards, which are all designed to stabilize, diversify, or intensify agricultural or pastoral activities. Agroforestry encompasses a diverse range of systems from planted hedgerows and pasture trees to crops (such as coffee) grown in the understories of older native forest (Schroth et al. 2004). Agroforestry and other on-farm tree systems often involve planting trees or assisting natural regeneration (Schroth et al. 2004).

The amount of carbon sequestered by agroforestry systems varies dramatically with the type of system implemented. As with plantations, many agroforestry and on-farm tree systems are not designed to result in permanent forest cover but are instead grown, cleared, or thinned, and then regenerated or replanted (Schroth et al. 2004), which could compromise long-term carbon sequestration and biodiversity benefits. These systems can also provide a valuable refuge for many forest species in the landscape. Wildlife species, however, are most often not the most threatened, nor those in conflict with human population, such as large carnivores or herbivores (Montagnini and Nair 2004, Jose 2009, Power 2010, Tscharntke et al. 2012). In general, agroforestry systems are more biodiverse than other types of agriculture but still contain fewer native species than primary forests, with the possible exception of regions where natural forests have relatively low biodiversity (McNeely and Schroth 2006, Schroth and Harvey 2007, Bhagwat et al. 2008, Power 2010, Phalan et al. 2011, Reji et al. 2011, Kremen and Miles 2012).

Agroforestry systems often produce food and other NTFPs in relatively high quantities compared to both native forests and plantations. Because agroforests are often implemented at a small scale, they can be strategically positioned in the landscape to maximize services; for example, in watersheds to protect water resources, in erosion-prone areas, in buffer zones alongside primary forest fragments to conserve biodiversity, and in silvopastoral systems to increase pasture productivity (Nair and Garrity 2012, Calle et al. 2013, McGroddy et al. 2015).

\section{CASE STUDIES OF FOREST TRANSITION TYPES}

To illustrate the diversity and changes in ecosystem services produced by different types of transitions, we present case studies from around the world where forest transitions of different types have occurred (Boxes 1-4). Cases were selected that (1) describe a range of different types of transitions; (2) have published studies on the ecosystem services arising from those transitions; and (3) are in locations where our co-authors have expert knowledge and access to data on context and ecosystem services. We describe the geography and history of forest and land use in each site, and compare the services provided to a primary forest reference site (Fig. 2, Boxes 1-4). We focused on ecosystem services that are amenable to being directly compared (preferably quantitatively) and that are highly regarded by people locally and globally.

New forests resulting from different transition types provide different suites of goods and services (Fig. 3). We observed that across all forest-transition types, compared to a primary forest baseline, services that are directly useful to people (e.g., timber, NTFPs) increased, while services with less direct/obvious utility (e.g., biodiversity) were lost (Fig. 3). This is consistent with other reviews of ecological service trade-offs following reforestation in montane areas (Locatelli et al. 2017), and highlights the anthropogenic nature of emergent forest landscapes and their ecosystems (Lugo 2009). The case studies also illustrate that spatial patterns of new forests are important: in all our case studies, reforestation was concentrated in proximity to water sources or aquifers, which resulted in relatively high water provision services per unit area of forest post transition.

Fig. 3. The services resulting from different forest-transition types based on case studies. Each service was compared to a primary forest baseline in the country in which the transition was occurring, and was given a score from -3 to 3 based on studies that quantified or described the services found in the secondary forests in each. A negative value indicates a reduction in a given ecosystem service after the forest-area inflection point relative to provision levels of primary forest; a positive value indicates an increase in a given ecosystem service. (NTFPs: nontimber forest products)

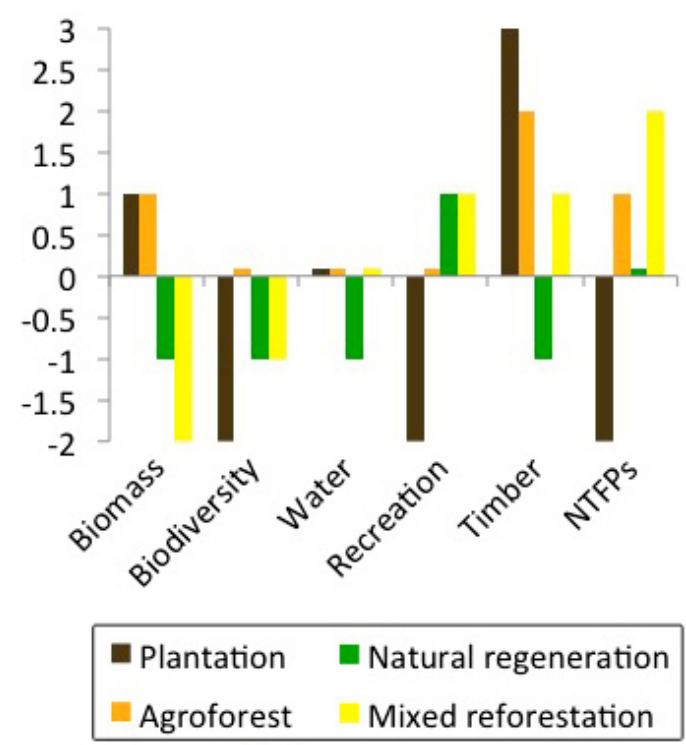




\section{Box 1. Plantation forestry: Misiones, Argentina}

Geography: Misiones is a province (c. $30,000 \mathrm{~km}^{2}$ ) in subtropical Argentina $\left(24-26^{\circ} \mathrm{S}\right)$, which contains one of the largest continuous areas of Atlantic Forest, a highly diverse ecoregion.

History: Misiones reached the lowest point of forest cover area in the 1990s (Chevez and Hilgert 2003) when government initiatives to halt deforestation included creating a biosphere reserve and several provincial reserves.

New forests: New forests expanded primarily as plantations of North American pines (Pinus ellioti and P. taeda) for pulp, paper, and saw wood. Plantations, owned by large companies, were established primarily on land that was previously used for shifting agriculture and established managed landscapes, which created riparian forest belts and corridors between native forest patches. Native forest cover has since remained stable, and because selective logging has decreased in protected areas, forests are likely recovering biodiversity. Shifting agriculture, the main historical driver of deforestation, has slowed due to government restrictions and rural-urban migration (Izquierdo et al. 2011).

Ecosystem services and products: Biomass and carbon content in these tree plantations have been found to be even higher than in native forests (Fassola et al. 2009). The strategic placement of these plantations in watersheds and erosion-prone areas means that per unit forest area, the watershed and soil services they provide are also greater (Izquierdo and Clark 2012). Plantations have much lower biodiversity than native forests but they do provide habitat for some species, especially in association with the corridors, and they frequently act as buffers of native forests, which limits access and expands the habitat for jaguars, peccaries, and other large vertebrates (Di Bittetti et al. 2006, Paviolo et al. 2008, Zurita et al. 2006). The economy of the province is dependent on forests for both industrial forest products and tourism (Izquierdo et al. 2008). Plantations are not used for recreational or aesthetic purposes (but they buffer protected areas that are). Tree plantations produce large volumes of timber and pulpwood. Nontimber forest products have declined because plantations produce primarily timber, and access to native forests by local populations is increasingly restricted by protected areas and plantations.

\section{Box 2. Agroforestry: African Sahel}

Geography: The Sahel is a semi-arid (rainfall 100-600 $\mathrm{mm}_{\text {year }}{ }^{-1}$ ) transitional ecoregion between the subtropical Sudanian woodlands to the south and the Sahara Desert to the north. It is dominated by savanna, grasslands, and scrublands.

History: People traditionally practiced extensive or migratory grazing, and cultivated millet and sorghum for subsistence. Following the droughts of the 1970s and 1980s, the Sahel (particularly in Chad and Burkina Faso) experienced a "greening" as precipitation levels returned to normal (Herrmann et al. 2005, Hickler et al. 2005, Olsson 2012, Seaquist et al. 2009) and people adopted adaptive land management techniques (Rasmussen et al.
2001, Mortimore and Turner 2005, Olsson et al. 2005, Reij et al. 2005, Reij 2006, Reij and Waters-Bayer 2014).

New forests: In response to droughts, landholders intensified soil and water conservation by protecting young forest to increase agro-ecological production and resilience (Reij 2006), and, to a lesser degree, planting trees (Reij et al. 2005). These practices produced forests with tree density that was comparable or superior to unmanaged woodlands (Mortimore and Turner 2005, Reij et al. 2005). Most new forests grew in managed areas and areas with relatively high population density, even as people continued to degrade forests along open-access peripheries (Mortimore and Turner 2005, Mortimore and Adams 2001). A perceived shift in economic rights to trees from the State to individual landholders greatly enhanced these efforts (Reij and Waters-Bayer 2014).

Ecosystem services and products: Carbon sequestration is significant (Olsson 2012) as new, dense forests span vast areas (Mortimore and Turner 2005, Reij 2006). Biodiversity likely increased as new forests contained many rare native tree species ( $89 \%$ of such species were found exclusively on managed lands) (Reij et al. 2005). Fuel wood and timber also increased (Mortimore and Turner 2005, Rudel 2005: Ch.7), but no other data on NTFPs are available. Higher water tables $(>5 \mathrm{~m})$ and local rainfall $(+30 \%)$ have been attributed to soil and water conservation efforts, including reforestation (Reij et al. 2005). Cereal yields (Reij et al. 2005) and fodder also increased following reforestation (Mortimore and Turner 2005, Rudel 2005: Ch.7), but this is indirectly and partially attributable to increased tree cover.

\section{Box 3. Spontaneous regeneration: Guanacaste, Costa Rica}

Geography: Guanacaste is a province $\left(10,141 \mathrm{~km}^{2}\right)$ in northwestern Costa Rica $\left(10.6^{\circ} \mathrm{N}\right)$. Volcanic mountains in the east drop down to a broad alluvial plain and beaches on the Pacific coast. Natural vegetation is predominantly tropical dry forest.

History: Widespread deforestation reduced forest cover to $23.6 \%$ of the province by 1975 . Driven by international beef markets and favorable policies for cattle, an expanding road network allowed smallholders who were pushed out of other regions of the country to colonize land, and government policies encouraged forest clearing (Calvo-Alvarado et al. 2009).

New forests: After a period of very low deforestation rates from 1979 to 1986 , forest cover began to increase and expanded to $47.9 \%$ of the province by 2005 (Kleinn et al. 2002). The transition is attributed to urbanization, a decline in the beef industry, a sharp drop in agricultural employment, a rise in service sector employment (particularly tourism), agricultural intensification in the lowlands, and conservation policies, including the establishment of protected areas, payments for ecosystem services, and restrictions on timber extraction and forest clearing (Calvo-Alvarado et al. 2009, Daniels 2010, McLennan and Garvin 2012). Spontaneous regeneration dominates the new forests, although the earliest regrowth on hilly terrain with coastal views was later cleared and fragmented for tourism and real estate development (Calvo-Alvarado et al. 2009), and tree plantations are concentrated on flatter land (Morera et al. 2007). 
Ecosystem services and products: Carbon stocks in primary forest are much higher than in regenerating forest (after nine and 21 years) (Hall et al. 2012). New forests are often strategically located in "forested protection zones" that have been created to provide drinking water and biodiversity corridors, and address stream corridor protection laws, and water improvement per unit forest area is likely high (Mata 2004). Biodiversity is highest in primary forest, but regenerating forests tend to have higher biodiversity than both plantations and nonforest areas (Hall et al. 2012). As forests recover, biodiversity increases due to increased habitat, greater connectivity, and lower edge-to-area ratios (Hall et al. 2012). However, because of complex pollination and migration patterns, fragmented landscapes are unlikely to approach the biodiversity of intact forest (Frankie et al. 2004). Most harvested timber comes from teak plantations (Piotto et al. 2004). The shift from rural to urban lifestyles, and a sharp decline in households cooking with fuel wood likely means that NTFPs (including fuel wood) are decreasing in importance to livelihoods (CalvoAlvarado et al. 2009).

\section{Box 4. Mixed transition: Intag Valley, Ecuador}

Geography: The Intag Valley (Imbabura, Ecuador) is a region in western Andean Ecuador. The valley is located 1100-3700 m above sea level, and receives $1600-2400 \mathrm{~mm}$ of precipitation per year. Vegetation ranges from premontane to upper montane cloud forest, with grasslands at higher elevations.

History: Intag's dense cloud forests were cleared rapidly in the 1970s, 1980s, and 1990s for agriculture and cattle ranching (Sarmiento 2002, Kocian et al. 2011). Forests were felled (sometimes after extracting timber), burned, planted with crops, and then converted to pasture. Like many Andean landscapes, soil fertility has declined over the past several decades (Jokisch 2002, Mayer 2002). Between 1991 and 2001, pastures and cropland expanded at the expense of intact and degraded forests, and the northeast portion of the valley lost $37 \%$ of its primary forest (Wilson 2015).

New forests: In response to severe declines in water quality and to seasonal droughts that followed deforestation, in the 1990s a local NGO helped communities establish more than 40 community-based watershed reserves for reforestation. The forest cover inflection point occurred in the early 2000 s at $40 \%$ cover, and between 2001 and 2010, forests returned on $26 \%$ of the land area for a net increase of $3 \%$. Forests returned through adopting agroforestry, planting native species along waterways, and spontaneous regrowth on agricultural land and pastures.

Ecosystem services and products: The carbon stock of primary forests in the region remains six times greater than in young naturally regenerating and restored forests (S. Wilson, unpublished data). Primary forest diversity is two times greater than in planted forests and four times greater than in spontaneously regenerating forests, which tended to be species poor and dominated by early successional species with low wood density. Planted forests had much higher tree diversity than spontaneously regenerating forests (Wilson and Rhemtulla 2016), while agroforests had intermediate diversity (S. Wilson, unpublished data). Residents reported improvements in water quality as new forests (natural, planted, agroforestry) were frequently established around waterways. However, compared to past conditions, water quality and quantity are still low and will likely take years to return to predeforestation conditions (Bruijnzeelet al. 2010). In the process of planting trees, people came to value them for the services they provide and developed new uses for them. The main forest products are fuel wood and timber. Planted forests contain more species that are used for timber, while naturally regenerating forest contain more species that are used for firewood. Planted forests contain more NTFP species (used for fertilizer, food, livestock fodder, and medicine) than both primary and naturally regenerating forests. Returning forests thus have both higher timber and NTFP potential value per unit forest area than do primary forests (Wilson and Rhemtulla 2016).

\section{FOREST ECOSYSTEM-SERVICE TRANSITION CURVES}

Our literature review and case studies demonstrate that different socio-economic changes yield different types of reforestation, ultimately giving rise to different suites of ecosystem services. These suites change and develop nonlinearly over the course of forest transition as forests mature and grow. To describe this development of ecosystem services coincident with reforestation, we propose conceptual "forest ecosystem-service transition curves" (Fig. 4), which illustrate how the type, amount, and trajectory of how ecosystem services change over the course of each transition type. These curves provide a framework for visualizing the ecosystem services that are likely to result from different types of transitions, and for estimating the long-term impacts of a transition from primary to secondary forest cover in different contexts. The conceptual curves presented here simplify the variability in actual reforestation outcomes, and are not intended to be rigorously quantitative (Norden et al. 2015). Instead, they indicate the relative amount of a given service that we might expect following a given type of forest transition. These estimated outcomes are based on our summary of the literature and consultations with leading experts in ecology, land use, cover change, and secondary forests through the PARTNERS reforestation research network (http://partners-rcn.org/).

The ecosystem-service curves illustrate the ecological implications of different forest transition types at local, national, or regional scales (Vallet et al. 2016). At a given scale, the suite of ecosystem services produced will depend on the dominant type of reforestation. To examine patterns and identify the ecological implications of these suites over time, in the next section we estimate the global distribution of different types of reforestation.

\section{GLOBAL DISTRIBUTION OF FOREST TRANSITION TYPES}

We estimated to what extent the new forest types (corresponding to our forest transition types) have expanded in different countries around the world. This analysis illustrates the relative global extent of different forms of reforestation and, by extension, their suites of ecosystem services. But more importantly, it pilots our curves as a framework for evaluating the ecological effects of forest transitions. 
Fig. 4. Forest ecosystem-service transition curves. The total forest cover depicted in a classic forest-transition curve is indicated by a solid line. Each panel shows conceptual curves of how quickly a given service recovers relative to forest area for each type of forest transition. (NTFP: nontimber forest product)

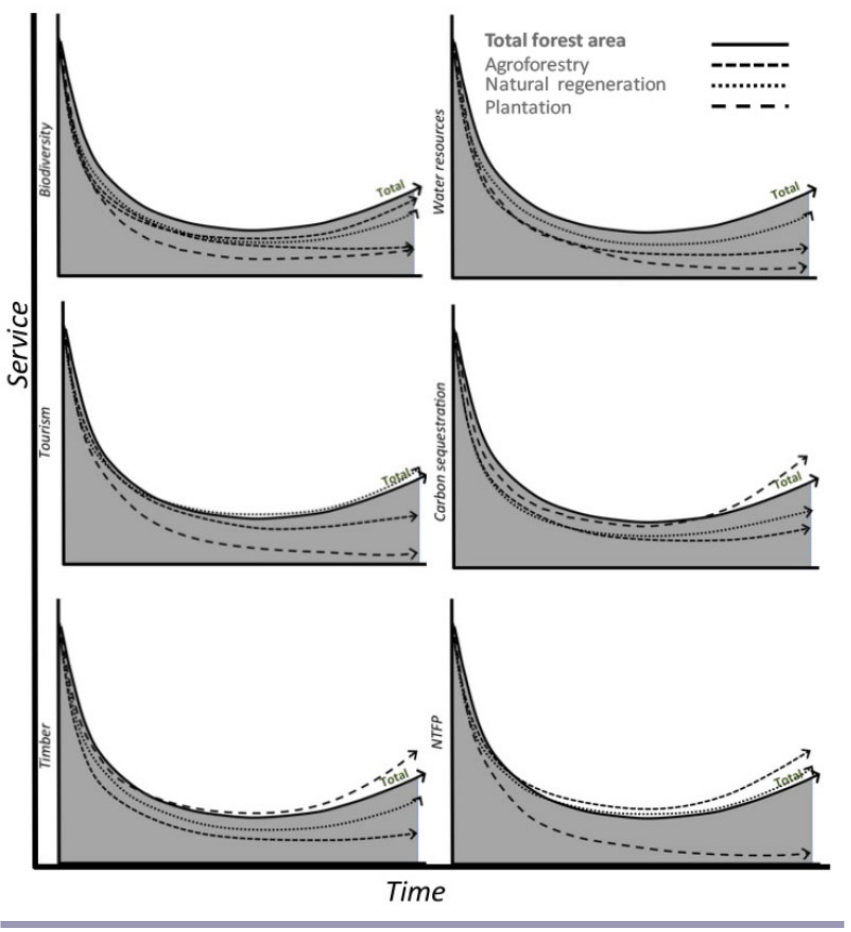

In our analysis, we estimated the dominant form of reforestation (plantation, agroforestry, natural, and mixed) for the 52 countries with the greatest gross gains in forest cover from 2000 to 2012 , proportional to the national area (Table 1, Fig. 5). Plantation reforestation was characterized by recently established tree plantations, agroforestry by forest regeneration on nominal agricultural lands, and spontaneous regeneration (likely owing to economic growth) by forest regeneration in other areas. We also defined a "mixed" reforestation class in which plantation reforestation and either agroforestry or spontaneous regeneration both occur at high levels $(>40 \%)$ in a given country (Table 1$)$. Our methodology is summarized in Appendix 1, and the final national classification is presented in Table 1.

\section{Prevalence of different types of regrowth globally}

In general, most countries experience appreciable regrowth of more than one forest type (Fig. 6A), which illustrates the complexity of forest transitions. However, several trends are still apparent with respect to regional ecological service transitions.

The dominant reforestation types tend to group regionally (Fig. 6). Plantation forests account for most of the new forests in regions with higher population densities (e.g., Central America, Western Europe, Japan, parts of Southeast Asia). This pattern would imply that timber, fibers, and short-term carbon sequestration are likely the dominant services derived from transitions, while biodiversity, NTFPs, and aesthetic or spiritual values are likely to be less common. On the other hand, plantations are often intentionally established for utilitarian purposes and have a clear role in human-dominated landscapes, which may increase the likelihood that they persist.

Regions with lower population densities (e.g., the boreal northern latitudes and South America) tend to show transitions through spontaneous regeneration, as did the higher population density Asia-Pacific region (Rudel et al. 2016). Spontaneous regeneration transitions were the most common type in the global south, generally, possibly due to high levels of rural-urban migration throughout (Aide and Grau 2004, Güneralp and Seto 2013, Hecht et al. 2015). This pattern contradicts the profile of the "tropical forest transition" defined by FAO Forest Resources Assessment data, which suggests that most tropical forest transitions occur through plantation reforestation (Sloan and Sayer 2015). The ecological implications of this difference are enormous; while plantation transitions tend to yield lower biodiversity, biodiversity in spontaneously regenerating forests can be relatively high. That most of the countries in our analysis experienced transitions through spontaneous regeneration is thus good news for biodiversity, especially as these transitions occurred disproportionately in the global south and Latin America, where from a global perspective, forest biodiversity tends to be highest (Aide and Grau 2004, Kreft and Jetz 2007).

Agroforestry and mixed transitions types are most common in Europe and in archipelagoes (Caribbean, Philippines) (Fig. 6B). Europe has many private, small-scale forests and sustainable forest management enterprises (Nabuurs et al. 2007, MacDicken et al. 2015), which could explain the prevalence there. Food production and associated services (e.g., water) are expected to result from transitions in the Philippines and the Caribbean.

Overall, our global analysis shows that forest transitions produce different "types" of new forests in different contexts, which lead to different groups of services that are geographically distributed. Anticipating the services that will result from a given transition type will help managers, governments, communities, and policymakers understand, anticipate, and plan for the present and future services that people can expect to receive from forests transitions, locally and globally.

\section{CONCLUSIONS}

Forest transition theory has provided a powerful framework for describing an important and previously neglected process of forest cover expansion. The use of a simplified metricundifferentiated forest cover-facilitated the wide application of this theory (Rudel et al. 2005, Chazdon et al. 2016). However, forest cover alone tells us little about the ecosystem services forest transitions provide, as they are driven by a variety of socialecological drivers that produce different forest types with different ecological functions, and ultimately, different ecosystem services. Our forest ecosystem-service transition curves provide a framework for understanding this global forest change that goes beyond coarse estimates of forest cover (Fig. 1, Fig. 4). This framework illustrates how the benefits of reforestation change over time as forests are cleared and return in different contexts. Linking underlying social and ecological conditions with the different new forests they produce and the associated levels of goods and services can help planners and policy-makers promote and adapt different strategies for forest recovery. 
Table 1. The 52 countries with the highest national proportional gross forest cover gain, and their dominant forest transition type. The dominant forest transition type was identified by the type of forest cover that accounted for most of the recovery ( $>50 \%$ ). When no forest type made up more than 50\%, the transition was recorded as "mixed". Since FAO forest resource assessment estimates of plantedforest gain are independent of Hansen estimates, forest gains through different pathways add to more than $100 \%$ when planted forest gains occur.

\begin{tabular}{|c|c|c|c|c|c|c|}
\hline \multirow[b]{2}{*}{ Country } & \multirow[b]{2}{*}{$\begin{array}{l}\text { Gross forest gain } \\
\qquad\left(\mathrm{km}^{2}\right)\end{array}$} & \multirow[b]{2}{*}{$\begin{array}{l}\text { Gross forest } \\
\text { gain (as \% of } \\
\text { national area) }\end{array}$} & \multicolumn{2}{|c|}{ Forest transition type determination } & \multirow[b]{2}{*}{$\begin{array}{l}\text { Plantations gain } \\
\text { (as } \% \text { of gross } \\
\text { forest gain) }\end{array}$} & \multirow[b]{2}{*}{ Forest transition type } \\
\hline & & & $\begin{array}{l}\text { Agroforestry gain } \\
\text { (as } \% \text { of gross } \\
\text { forest gain) }\end{array}$ & $\begin{array}{c}\text { Natural } \\
\text { regeneration gain } \\
\text { (as } \% \text { of gross } \\
\text { forest gain) }\end{array}$ & & \\
\hline Russia & 162292 & 0.98 & 19.0 & 81.0 & 10.0 & Natural regeneration \\
\hline United States & 138082 & 1.52 & 10.0 & 90.0 & 20.3 & Natural regeneration \\
\hline Canada & 91071 & 1.07 & 21.0 & 79.0 & 34.5 & Natural regeneration \\
\hline Brazil & 75866 & 0.9 & 15.9 & 84.1 & 29.6 & Natural regeneration \\
\hline Indonesia & 69701 & 3.7 & 30.2 & 69.8 & -1.8 & Natural regeneration \\
\hline Malaysia & 25798 & 7.86 & 39.0 & 61.0 & 5.7 & Natural regeneration \\
\hline Sweden & 15281 & 3.71 & 1.7 & 98.3 & 3.7 & Natural regeneration \\
\hline Chile & 14611 & 1.59 & 9.6 & 90.4 & 30.7 & Natural regeneration \\
\hline Finland & 10849 & 3.56 & 2.8 & 97.2 & 87.4 & Mixed reforestation \\
\hline South Africa & 8313 & 0.7 & 5.0 & 95.0 & 4.7 & Natural regeneration \\
\hline New Zealand & 7102 & 2.68 & 6.5 & 93.5 & 0.4 & Natural regeneration \\
\hline Vietnam & 5643 & 1.75 & 38.8 & 61.2 & 259.1 & Plantation \\
\hline France & 5062 & 0.92 & 47.0 & 53.0 & 7.9 & Natural regeneration \\
\hline Poland & 5041 & 1.65 & 46.5 & 53.5 & 48.4 & Mixed reforestation \\
\hline Thailand & 4992 & 0.95 & 70.5 & 29.5 & 175.3 & Plantation \\
\hline Uruguay & 4965 & 2.95 & 13.7 & 86.3 & 62.2 & Mixed reforestation \\
\hline Spain & 4482 & 1.03 & 33.7 & 66.3 & 39.0 & Natural regeneration \\
\hline Madagascar & 4051 & 0.69 & 18.6 & 81.4 & 35.3 & Natural regeneration \\
\hline Belarus & 3755 & 1.8 & 48.5 & 51.5 & 43.9 & Mixed reforestation \\
\hline Ukraine & 3529 & 0.62 & 53.8 & 46.2 & 25.8 & Agroforestry \\
\hline Laos & 3379 & 1.48 & 8.4 & 91.6 & 37.0 & Natural regeneration \\
\hline Portugal & 2866 & 3.22 & 14.9 & 85.1 & 25.5 & Natural regeneration \\
\hline Philippines & 2726 & 0.92 & 53.9 & 46.1 & 9.2 & Agroforestry \\
\hline Germany & 2582 & 0.74 & 30.1 & 69.9 & 0.0 & Natural regeneration \\
\hline Japan & 2570 & 0.72 & 13.6 & 86.4 & -1.9 & Natural regeneration \\
\hline Ivory Coast & 2298 & 0.73 & 24.6 & 75.4 & 33.1 & Natural regeneration \\
\hline Cuba & 2271 & 2.1 & 88.1 & 11.9 & 63.4 & Mixed reforestation \\
\hline Latvia & 1857 & 2.93 & 26.6 & 73.4 & -43.6 & Natural regeneration \\
\hline Romania & 1530 & 0.66 & 37.9 & 62.1 & 29.4 & Natural regeneration \\
\hline Hungary & 1350 & 1.46 & 76.0 & 24.0 & 76.3 & Mixed reforestation \\
\hline Czech Republic & 1331 & 1.69 & 36.4 & 63.6 & 14.3 & Natural regeneration \\
\hline Ireland & 1238 & 1.75 & 3.7 & 96.3 & 84.0 & Mixed reforestation \\
\hline Lithuania & 1226 & 1.93 & 43.0 & 57.0 & 48.9 & Mixed reforestation \\
\hline Cambodia & 1096 & 0.62 & 19.4 & 80.6 & -9.1 & Natural regeneration \\
\hline Guatemala & 1094 & 1 & 39.8 & 60.2 & 73.1 & Mixed reforestation \\
\hline Liberia & 1084 & 1.12 & 11.6 & 88.4 & 0.0 & Natural regeneration \\
\hline Estonia & 894 & 2.05 & 25.6 & 74.4 & -2.2 & Natural regeneration \\
\hline Austria & 658 & 0.78 & 17.3 & 82.7 & 0.0 & Natural regeneration \\
\hline Swaziland & 603 & 3.47 & 3.3 & 96.7 & -16.6 & Natural regeneration \\
\hline Slovakia & 523 & 1.06 & 22.4 & 77.6 & 1.9 & Natural regeneration \\
\hline Sierra Leone & 451 & 0.62 & 13.6 & 86.4 & 15.5 & Natural regeneration \\
\hline Dominican Republic & 393 & 0.81 & 71.6 & 28.4 & 0.0 & Agroforestry \\
\hline Costa Rica & 382 & 0.74 & 54.9 & 45.1 & 99.5 & Plantation \\
\hline Belgium & 373 & 1.24 & 26.3 & 73.7 & -32.2 & Natural regeneration \\
\hline Denmark & 322 & 0.79 & 59.6 & 40.4 & 142.9 & Plantation \\
\hline Solomon Islands & 203 & 0.74 & 9.2 & 90.8 & -4.9 & Natural regeneration \\
\hline Fiji & 119 & 0.67 & 26.8 & 73.2 & 395.0 & Plantation \\
\hline Brunei & 88 & 1.54 & 25.0 & 75.0 & 22.7 & Natural regeneration \\
\hline Jamaica & 68 & 0.62 & 65.6 & 34.4 & -14.7 & Agroforestry \\
\hline Puerto Rico & 64 & 0.72 & 68.5 & 31.5 & 0.0 & Agroforestry \\
\hline Mauritius & 30 & 1.56 & 82.8 & 17.2 & 0.0 & Agroforestry \\
\hline Luxembourg & 27 & 1.04 & 40.8 & 59.2 & 0.0 & Natural regeneration \\
\hline
\end{tabular}


Fig. 5. Gross increase in forest cover as a percentage national area, for the top 52 countries, 2000-2012.

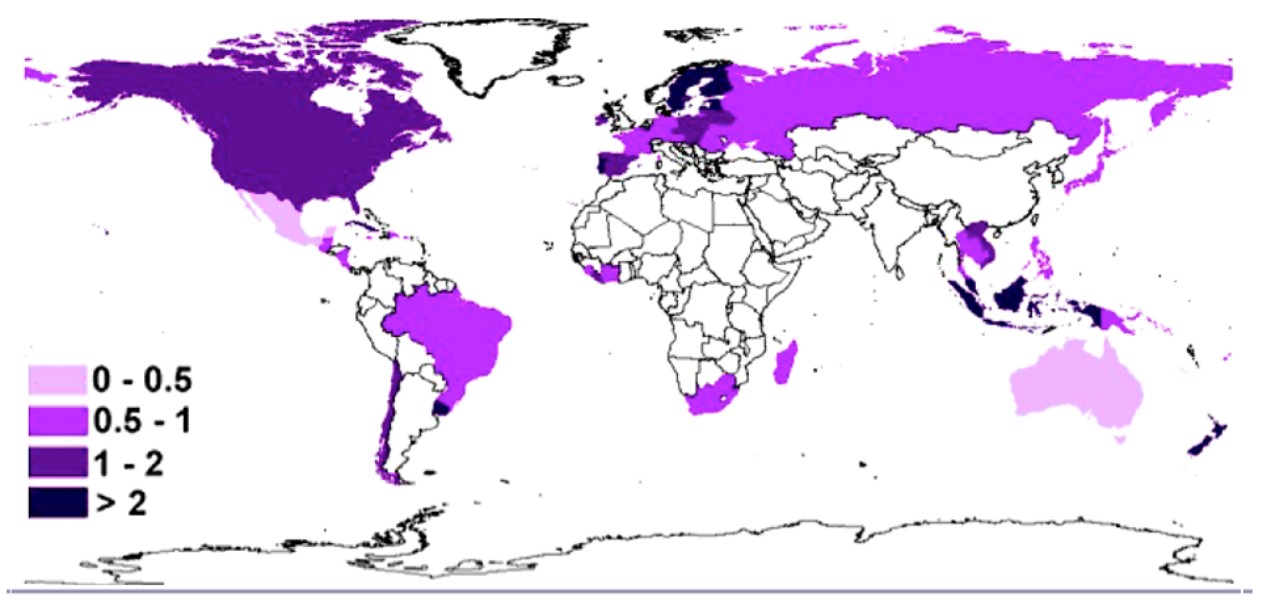

Fig. 6. Types of reforestation occurring in the countries experiencing the greatest gains in gross forest cover as a proportion of their national area, 2000-2012. (A) Reforested area by type, as a proportion of gross forest cover gain. (B) The dominant ( $>50 \%$ ) form of reforestation by which forest cover increased, based on the relative proportion of different secondary forest types.

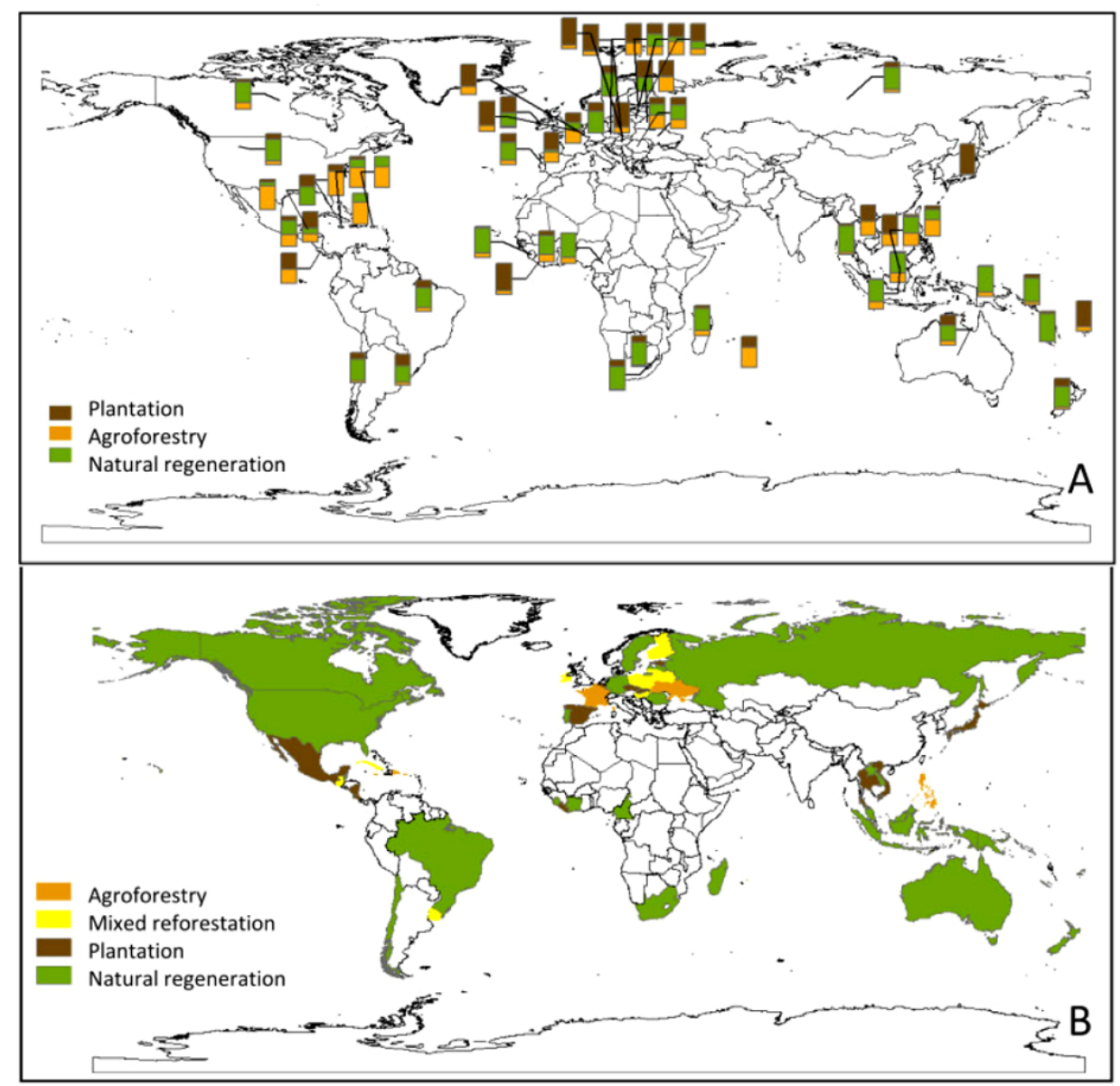


We have provided an overview of forest and ecosystem-service transitions, combined with detailed local examples. The "forest ecosystem-service transition" concept will only become more rigorous and applicable for describing services gained and lost as global data sets are improved and systematically linked to detailed case studies. Our global analysis of regionally dominant reforestation types was limited by a lack of consistent global data sets that differentiate between secondary forest types (Hansen et al. 2013, Chazdon et al. 2016). This limitation highlights a need for global spatial data on agroforestry, which currently do not exist, and for better remote sensing products generally that discriminate between new forest types. Although some techniques exist to identify changing forest types over time (Fagan et al. 2015), they have been applied only at relatively small scales. Combining satellite-based indicators of ecological function with census statistics on land use and human population, or with participatory remote sensing methods, are potential avenues to yield a more rigorous classification of forest types (Chazdon et al. 2016). A complementary and promising (but labor-intensive) avenue is visually interpreting agroforestry and planted forests using highresolution satellite imagery, as has been conducted at regional scales (Miettinen and Liew 2010) and for select countries (World Resources Institute Global Forest Watch http://www. globalforestwatch.org/).

Case studies provide nuanced analyses that integrate diverse economic and cultural factors, show complex patterns of forest recovery, and provide corresponding data on ecosystem services, as we have demonstrated. Meta-analyses of case studies could potentially refine our ecosystem-service transition models. But to date, case studies that track multiple services over time are rare, and case study data are often incomplete. We found many cases where one or a couple of ecosystem services were quantified, but the scope for quantitative comparisons was limited by a lack of consistency among cases in terms of which services were measured, by which metrics, and relative to which baseline. Case studies are needed that (1) examine a broad array of ecosystem services produced by different types of secondary forests at different ages, and (2) use comparable sets of metrics to assess these services. The forest ecosystem-service framework could serve as a guide to design studies at specific locations that represent important cases of interest.

Despite data limitations, our analysis illustrates why and how forest transitions differ from each other, socially, ecologically, and regionally. The proportion of different forms of reforestation and their corresponding suites of ecosystem services vary dramatically among different world regions. According to our framework and global analysis, biodiversity is likely relatively high (relative to other forms of reforestation) in the global south, and in particular, Latin America (although it is still lower than in the primary forests that were cleared). The production of timber, carbon, and fibers is likely high in plantation transition regions in the Western Europe and the Asia-Pacific regions, perhaps in part because the scarcity of these services is felt more acutely in these areas of high population density (Mather 1992, Rudel et al. 2005). A wide range of services likely occurs in the Philippines, Caribbean, and other parts of Europe, areas which have mixed transitions and agroforestry transitions.

Our case studies show that patterns in the types of new forests reflect differences in underlying social, economic, and ecological conditions. This creates both challenges and advantages in terms of both the ease of promoting forest recovery (through education, policies, and management), and in anticipating the suite of ecosystem services they ultimately produce (Sloan 2015, 2016). However, new forests and forest transitions provide an important opportunity to partially reverse historical environmental degradation. Because different forest transition types enable different cobenefits, policy-makers and practitioners can use our framework to guide choices about what types of transitions to promote to achieve specific end goals at regional and global scales, as in the context of REDD+ or multilateral reforestation initiatives like the Bonn Challenge.

Our study points to a particular win-win in that forest transitions are likely to enhance soil and watershed conservation, since new forests tend to be located in riverine and steep areas where competition with industrial agriculture is minimized. This pattern occurs both because of intentional actions (i.e., establishing plantations or forests to protect water supplies) and as a byproduct of agricultural intensification (i.e., when farming technologies are introduced and marginal land is abandoned), and it can be strategically built upon elsewhere.

With respect to planning for different services, carbon sequestration will be comparatively lower in agroforestry transitions, whereas biodiversity recovery is likely to be lower in industrial plantations. Naturally regenerating forests usually have highest biodiversity and relatively large biomass but tend to provide less provisioning and economically valuable services. Understanding the tendency for different socio-economic drivers to produce different forest-transition types provides us with an opportunity to promote and manage new forests in a way that meets the needs of populations, and to contribute to environmental goals, such as mitigating climate change and biodiversity loss. We encourage other researchers to elaborate on and test the forest ecological-service transition curves we have outlined, and to develop this framework for policy application.

Responses to this article can be read online at: http://www.ecologyandsociety.org/issues/responses. $\mathrm{php} / 9615$

\section{Acknowledgments:}

The authors wish to thank members of the PARTNERS Restoration Network for supporting this work; in particular, Robin Chazdon and Tom Rudel for their input in both design and editorial phases of the paper; members of the Forest Transitions working group, and those who contributed to our ranking exercise. Funding for PARTNERS was provided by the National Science Foundation.

\section{LITERATURE CITED}

Abbas, S., J. E. Nichol, and G. A. Fischer. 2016. A 70-year perspective on tropical forest regeneration. Science of the Total Environment 544:544-552. http://dx.doi.org/10.1016/j. scitotenv.2015.11.171

Aide, T. M., M. L. Clark, H. R. Grau, D. López-Carr, M. A. Levy, D. Redo, M. Bonilla-Moheno, G. Riner, M. J. Andrade-Núñez, and M. Muñiz. 2013. Deforestation and reforestation of Latin 
America and the Caribbean (2001-2010). Biotropica 45(2):262271. http://dx.doi.org/10.1111/j.1744-7429.2012.00908.x

Aide, T. M., and H. R. Grau. 2004. Globalization, migration and Latin American ecosystems. Science 305:1915-1916. http://dx. doi.org/10.1126/science. 1103179

Aide, T. M., M. C. Ruiz-Jaen, and H. R. Grau. 2010. What is the state of tropical montane cloud forest restoration? Pages 101-110 in L. A. Bruijnzeel, F. N. Scatena, and L. S. Hamilton, editors. Tropical montane cloud forests: science for conservation and management. Cambridge University Press, Cambridge.

Aide, T. M., J. K. Zimmerman, J. B. Pascarella, L. Rivera, and H. Marcano-Vega. 2000. Forest regeneration in a chronosequence of tropical abandoned pastures: implications for restoration ecology. Restoration Ecology 8:328-338. http://dx.doi.org/10.1046/ j.1526-100x.2000.80048.x

Alvarez, J. A., P. E. Villagra, R. Villalba, and G. Debandi. 2013. Effects of the pruning intensity and tree size on multi-stemmed Prosopis flexuosa trees in the Central Monte, Argentina. Forest Ecology and Management 310:857-864. http://dx.doi.org/10.1016/ j.foreco.2013.09.033

Angonese, J. G., and H. R. Grau. 2014. Assessment of swaps and persistence in land cover changes in a subtropical periurban region, NW Argentina. Landscape and Urban Planning 127:8393. http://dx.doi.org/10.1016/j.landurbplan.2014.01.021

Bentley, J. W. 1989. Bread forests and new fields: the ecology of reforestation and forest clearing among small-woodland owners in Portugal. Forest \& Conservation History 33(4):188-195. http:// dx.doi.org/10.2307/4005155

Bhagwat, S. A., K. J. Willis, H. J. Birks, and R. J. Whittaker. 2008. Agroforestry: a refuge for tropical biodiversity? Trends in Ecology \& Evolution 23:261-267. http://dx.doi.org/10.1016/j.tree.2008.01.005

Brechin, S. R. 1997. Planting trees in the developing world: a sociology of international organizations. Johns Hopkins University Press, Baltimore, Maryland, USA.

Brechin, S. R., and W. Kempton. 1994. Global environmentalism: a challenge to the postmaterialism thesis? Social Science Quarterly 75:245-269.

Brown, S., and A. E. Lugo. 1990. Tropical secondary forests. Journal of Tropical Ecology 6(1):1-32. http://dx.doi.org/10.1017/ $\underline{\mathrm{S} 0266467400003989}$

Bruijnzeel, S., F. Scatena, and L. S. Hamilton, editors. 2010. Tropical montane cloud forests: science for conservation and management. Cambridge University Press. http://dx.doi. org/10.1017/CBO9780511778384

Calle, Z., E. Murgueitio, J. Chará, C. H. Molina, A. F. Zuluaga, and A. Calle. 2013. A strategy for scaling-up intensive silvopastoral systems in Colombia. Journal of Sustainable Forestry 32:677-693. http://dx.doi.org/10.1080/10549811.2013.817338

Calvo-Alvarado, J., B. McLennan, A. Sánchez-Azofeifa, and T. Garvin. 2009. Deforestation and forest restoration in Guanacaste, Costa Rica: putting conservation policies in context. Forest Ecology and Management 258:931-940. http://dx.doi.org/10.1016/ j.foreco.2008.10.035
Chai, S.-L., and E. V. J. Tanner. 2011. 150-year legacy of land use on tree species composition in old-secondary forests of Jamaica. Journal of Ecology 99:113-121. http://dx.doi.org/10.1111/ j.1365-2745.2010.01742.x

Chazdon, R. L. 2003. Tropical forest recovery: legacies of human impact and natural disturbances. Perspectives in Plant Ecology, Evolution and Systematics 6:51-71. http://dx.doi. org/10.1078/1433-8319-00042

Chazdon, R. L. 2008. Beyond deforestation: restoring forests and ecosystem services on degraded lands. Science 320:1458-1460. http://dx.doi.org/10.1126/science.1155365

Chazdon, R. L. 2014. Second growth: the promise of tropical forest regeneration in an age of deforestation. University of Chicago Press, Chicago, Illinois, USA.

Chazdon, R. L., P. H. S. Brancalion, L. Laestadius, B. BennettCurry, K. Buckingham, C. Kumar, J. Moll-Rocek, I. C. Guimarães Vieira, and S. J. Wilson. 2016. When is a forest a forest? Forest concepts and definitions in the era of forest and landscape restoration. Ambio 45:538-550. http://dx.doi.org/10.1007/ s13280-016-0772-y

Chazdon, R. L., S. Careaga, C. Webb, and O. Vargas. 2003. Community and phylogenetic structure of reproductive traits of woody species in wet tropical forests. Ecological Monographs 73:331-348. http://dx.doi.org/10.1890/02-4037

Chevez, J. N., and N. Hilgert. 2003. A brief history of conservation in Parana forest. In N. Galindo-Leal, and I. de Gusmão Câmara, editors. The Atlantic Forest of South America: biodiversity status, threats, and outlook. Island Press and Center for Applied Biodiversity Science at Conservation International, Washington.

Cohen, S. E. 2004. Planting nature: trees and the manipulation of environmental stewardship in America. University of California Press, Berkeley, California, USA.

Cramer, V. A., R. J. Hobbs, and R. J. Standish. 2008. What's new about old fields? Land abandonment and ecosystem assembly. Trends in Ecology \& Evolution 23:104-112. http://dx.doi. org/10.1016/j.tree.2007.10.005

Daniels, A. E. 2010. Forest expansion in northwest Costa Rica: conjuncture of the global market, land-use intensification, and forest protection. Pages 227-252 in H. Nagendra and J. Southworth, editors. Reforesting landscapes linking pattern and process. Springer, Dordrecht, Netherlands. http://dx.doi. org/10.1007/978-1-4020-9656-3 10

Deneven, W. M., J. M. Treacy, J. B. Alcorn, C. Padoch, J. Denslow, and S. F. Paitan. 1984. Indigenous agroforestry in the Peruvian Amazon: Bora Indian management of swidden fallows. Interciencia 9:346-357.

Dent, D. H., and S. J. Wright. 2009. The future of tropical species in secondary forests: a quantitative review. Biological Conservation 142:2833-2843. http://dx.doi.org/10.1016/j.

biocon.2009.05.035

Díaz, S., A. Hector, and D. A. Wardle. 2009. Biodiversity in forest carbon sequestration initiatives: not just a side benefit. Current Opinion in Environmental Sustainability 1:55-60. http://dx.doi. org/10.1016/j.cosust.2009.08.001 
Di Bitetti, M., A. Paviolo, and C. De Angelo. 2006. Density, habitat use and activity patterns of ocelots (Leoparduspardalis) in the Atlantic Forest of Misiones, Argentina. Journal of Zoology 270:153-163.

Fagan, M. E., R. S. DeFries, S. E. Sesnie, J. P. Arroyo-Mora, C. Soto, A. Singh, et al. 2015. Mapping species composition of forests and tree plantations in northeastern Costa Rica with an integration of hyperspectral and multitemporal Landsat imagery. Remote Sensing 7:5660-5696. http://dx.doi.org/10.3390/rs70505660

Fassola, H. E., E. H. Crechi, S. R. Barth, A. E. Keller, R. A. Winck, R. Martiarena, A. Von Wallis, M. A. Pinazo, and O. Knebel. 2009. Models for above-ground biomass estimation of Pinustaeda in Misiones and NE Corrientes region, Argentina. Internal Report. INTA EEA Montearlo, Misiones, Argentina.

Florentine, S. K., and M. E. Westbrooke. 2004. Restoration on abandoned tropical pasturelands - do we know enough? Journal for Nature Conservation 12:85-94. http://dx.doi.org/10.1016/j. inc. 2003.08.003

Food and Agricultural Organization of the United Nations (FAO). 2010. Global forest resources assessment 2010: main report. FAO Forestry Paper. Rome, Italy.

Food and Agricultural Organization of the United Nations (FAO). 2011. State of the world's forests 2011. Rome, Italy.

Food and Agricultural Organization of the United Nations (FAO). 2015. Global forest resources assessment 2015. FAO Forestry Paper. Rome, Italy.

Foster, A. D., and M. R. Rosenzweig. 2003. Economic growth and the rise of forests. Quarterly Journal of Economics 118:601637. http://dx.doi.org/10.1162/003355303321675464

Foster, D., F. Swanson, J. Aber, I. Burke, N. Brokaw, D. Tilman, and A. Knapp. 2003. The importance of land-use legacies to ecology and conservation. BioScience 53:77-88. http://dx.doi. org/10.1641/0006-3568(2003)053[0077:TIOLUL]2.0.CO;2

Frankie, G. W., W. A. Haber, S. B. Vinson, K. S. Bawa, P. S. Ronchi, and N. Zamora. 2004. Flowering phenology and pollination systems diversity in the seasonal dry forest. Pages 17-29 in G. W. Frankie, A. Mata, and S. B. Vinson, editors. Biodiversity conservation in Costa Rica: learning the lessons in a seasonal dry forest. University of California Press, Berkeley, California, USA.

Frankie, G. W., A. Mata, and S. B. Vinson, editors. 2004. Biodiversity conservation in Costa Rica: learning the lessons in a seasonal dry forest. University of California Press, Berkeley, California, USA.

Gibson, L., T. M. Lee, L. P. Koh, B. W. Brook, T. A. Gardner, J. Barlow, C. A. Peres, C. J. A. Bradshaw, W. F. Laurance, T. E. Lovejoy, and N. S. Sodhi. 2011. Primary forests are irreplaceable for sustaining tropical biodiversity. Nature 478:378-381. http:// dx.doi.org/10.1038/nature10425

Grainger, A. 1995. The forest transition: an alternative approach. Area 27:242-251.

Grau, H. R., T. M. Aide, J. K. Zimmerman, J. R. Thomlinson, E. Helmer, and X. Zou. 2003. The ecological consequences of socioeconomic and land-use changes in postagriculture Puerto
Rico. BioScience 53(12):1159-1168. http://dx.doi.org/10.1641/0006-3568 (2003)053[1159:TECOSA]2.0.CO;2

Grau, H. R., M. E. Hernández, J. Gutierrez, N. I. Gasparri, M. C. Casaveccia, E. Flores-Ivaldi, and L. Paolini. 2008. A periurban neotropical forest transition and its consequences for environmental services. Ecology and Society 13(1):35. http://dx. doi.org/10.5751/ES-02434-130135

Guariguata, M. R., and R. Ostertag. 2001. Neotropical secondary forest succession: changes in structural and functional characteristics. Forest Ecology and Management 148:185-206. http://dx.doi.org/10.1016/S0378-1127(00)00535-1

Güneralp, B., and K. C. Seto. 2013. Futures of global urban expansion: uncertainties and implications for biodiversity conservation. Environmental Research Letters 8:014025. http://dx. doi.org/10.1088/1748-9326/8/1/014025

Hall, J. M., T. Van Holt, A. E. Daniels, V. Balthazar, and E. F. Lambin. 2012. Trade-offs between tree cover, carbon storage and floristic biodiversity in reforesting landscapes. Landscape Ecology 27:1135-1147. http://dx.doi.org/10.1007/s10980-012-9755-y

Hansen, M., P. Potapov, R. Margono, S. Stehman, S. Turubanova, and A. Tyukavina. 2014. Response to comment on "Highresolution global maps of 21 st-century forest cover change". Science 344:981. http://dx.doi.org/10.1126/science.1248817

Hansen, M. C., P. V. Potapov, R. Moore, M. Hancher, S. A. Turubanova, A. Tyukavina, D. Thau, S. V. Stehman, S. J. Goetz, T. R. Loveland, A. Kommareddy, A. Egorov, L. Chini, C. O. Justice, and J. R. G. Townshend. 2013. High-resolution global maps of 21st-century forest cover change. Science 342:850-853. http://dx.doi.org/10.1126/science.1244693

Healey, S. P., and R. I. Gara. 2003. The effect of a teak (Tectona grandis) plantation on the establishment of native species in an abandoned pasture in Costa Rica. Forest Ecology and Management 176:497-507. http://dx.doi.org/10.1016/S0378-1127 (02)00235-9

Hecht, S. B., S. Kandel, I. Gomes, N. Cuellar, and H. Rosa. 2006. Globalization, forest resurgence, and environmental politics in El Salvador. World Development 34:308-323. http://dx.doi. org/10.1016/j.worlddev.2005.09.005

Hecht, S. B., and S. S. Saatchi. 2007. Globalization and forest resurgence: changes in forest cover in El Salvador. BioScience 57:663-673. http://dx.doi.org/10.1641/B570806

Hecht, S., A. L. Yang, B. S. Basnett, C. Padoch, and N. L. Peluso. 2015. People in motion, forests in transition: trends in migration, urbanization, and remittances and their effects on tropical forests. Occasional Paper 142. CIFOR, Bogor, Indonesia.

Herrmann, S. M., A. Anyamba, and C. J. Tucker. 2005. Recent trends in vegetation dynamics in the African Sahel and their relationship to climate. Global Environmental Change 15:94- 404. http://dx.doi.org/10.1016/j.gloenvcha.2005.08.004

Hickler, T., L. Eklundh, J. W. Seaquist, B. Smith, J. Ardö, L. Olsson, M. T. Sykes, and M. Sjöström. 2005. Precipitation controls Sahel greening trend. Geophysical Research Letters 32 (1). http://dx.doi.org/10.1029/2005GL024370 
Holl, K. D., M. E. Loik, E. H. V. Lin, and I. A. Samuels. 2000. Tropical montane forest restoration in Costa Rica: overcoming barriers to dispersal and establishment. Restoration Ecology 8:339-349. http://dx.doi.org/10.1046/j.1526-100x.2000.80049.x

Izquierdo, A. F., and M. L. Clark. 2012. Spatial analysis of conservation priorities based on ecosystem services in the Atlantic Forest region of Misiones, Argentina. Forests 3:764-786. http:// dx.doi.org/10.3390/f3030764

Izquierdo, A., C. DáAngelo, and T. M. Aide. 2008. Thirty years of human demography and land-use change in the Atlantic Forest of Misiones, Argentina: an evaluation of the forest transition model. Ecology and Society 13(2):3. http://dx.doi.org/10.5751/ ES-02377-130203

Izquierdo, A. E., H. R. Grau, and T. M. Aide. 2011. Implications of rural-urban migration for conservation of the Atlantic Forest and urban growth in Misiones, Argentina (1970-2013). Ambio 40:298-309. http://dx.doi.org/10.1007/s13280-010-0095-3

Jackson, R. B., E. G. Jobbágy, R. Avissar, S. B. Roy, D. J. Barrett, C. W. Cook, K. A. Farley, D. C. Le Maitre, B. A. McCarl, and B. C. Murray. 2005. Trading water for carbon with biological carbon sequestration. Science 310:1944-1947. http://dx.doi.org/10.1126/ science. 1119282

Jactel, H., E. Brockerhoff, and P. Duelli. 2005. A test of the Biodiversity-Stability Theory: meta-analysis of tree species diversity effects on insect pest infestations, and re-examination of responsible factors. Pages 235-262 in M. Scherer-Lorenzen, C. Körner, and E. Schulze, editors. Forest diversity and function: temperate and boreal systems. Springer-Verlag, Berlin, Germany. http://dx.doi.org/10.1007/3-540-26599-6 12

Jokisch, B. D. 2002. Migration and agricultural change: the case of smallholder agriculture in highland Ecuador. Human Ecology 30:523-550. http://dx.doi.org/10.1023/A:1021198023769

Jose, S. 2009. Agroforestry for ecosystem services and environmental benefits: an overview. Agroforestry Systems 76:110. http://dx.doi.org/10.1007/s10457-009-9229-7

Kanowski, J., C. P. Catterall, and G. W. Wardell-Johnson. 2005. Consequences of broadscale timber plantations for biodiversity in cleared rainforest landscapes of tropical and subtropical Australia. Forest Ecology and Management 208:359-372. http:// dx.doi.org/10.1016/j.foreco.2005.01.018

Kauppi, P. E., J. H. Ausubel, J. Fang, A. S. Mather, R. A. Sedjo, and P. E. Waggoner. 2006. Returning forests analyzed with the forest identity. Proceedings of the National Academy of Sciences of the United States of America 103:17574-17579. http://dx.doi. org/10.1073/pnas.0608343103

Kirby, K. R., and C. Potvin. 2007. Variation in carbon storage among tree species: implications for the management of a smallscale carbon sink project. Forest Ecology and Management 246:208-221. http://dx.doi.org/10.1016/j.foreco.2007.03.072

Klanderud, K., H. Z. H. Mbolatiana, M. N. Vololomboahangy, M. A. Radimbison, E. Roger, Ø. Totland, and C. Rajeriarison. 2010. Recovery of plant species richness and composition after slash-and-burn agriculture in a tropical rainforest in Madagascar. Biodiversity and Conservation 19:187-204. http://dx.doi. org/10.1007/s10531-009-9714-3
Kleinn, C., L. Corrales, and D. Morales. 2002. Forest area in Costa Rica: a comparative study of tropical forest cover estimates over time. Environmental Monitoring and Assessment 73:17-40. http://dx.doi.org/10.1023/A:1012659129083

Kocian, M., D. Batker, and J. Harrison-Cox. 2011. An ecological study of Ecuador's Intag region: the environmental impacts and potential rewards of mining. Earth Economics, Tacoma, Washington, USA.

Kraenzel, M., A. Castillo, T. Moore, and C. Potvin. 2003. Carbon storage of harvest-age teak (Tectona grandis) plantations, Panama. Forest Ecology and Management 173:213-225. http://dx. doi.org/10.1016/S0378-1127(02)00002-6

Kreft, H., and W. Jetz. 2007. Global patterns and determinants of vascular plant diversity. Proceedings of the National Academy of Sciences of the United States of America 104(14):5925-5930. http://dx.doi.org/10.1073/pnas.0608361104

Kremen, C., and A. Miles. 2012. Ecosystem services in biologically diversified versus conventional farming systems: benefits, externalities, and trade-offs. Ecology and Society 17 (4):40. http://dx.doi.org/10.5751/ES-05035-170440

Kuemmerle, T., P. Olofsson, O. Chaskovskyy, M. Baumann, K. Ostapowicz, C. E. Woodcock, R.A. Houghton, P. Hostert, W. S. Keeton, and V. C. Radeloff. 2011. Post-Soviet farmland abandonment, forest recovery, and carbon sequestration in western Ukraine. Global Change Biology 17:1335-1349. http://dx. doi.org/10.1111/j.1365-2486.2010.02333.X

Kull, C. A., C. K. Ibrahim, and T. C. Meredith. 2007. Tropical forest transitions and globalization: neo-liberalism, migration, tourism, and international conservation agendas. Society \& Natural Resources 20(8):723-737. http://dx.doi.org/10.1080/08941920701329702

Laclau, P. 2003. Biomass and carbon sequestration of ponderosa pine plantations and native cypress forests in northwest Patagonia. Forest Ecology and Management 180:317-333. http:// dx.doi.org/10.1016/S0378-1127(02)00580-7

Lamb, D., P. D. Erskine, and J. A. Parrotta. 2005. Restoration of degraded tropical forest landscapes. Science 310:1628-1632. http://dx.doi.org/10.1126/science.1111773

Lambin, E. F., and P. Meyfroidt. 2010. Land use transitions: socio-ecological feedback versus socio-economic change. Land Use Policy 27:108-118. http://dx.doi.org/10.1016/j.landusepol.2009.09.003

Locatelli, B., C. P. Catterall, P. Imbach, C. Kumar, R. Lasco, E. Marín-Spiotta, B. Mercer, J. S. Powers, N. Schwartz, and M. Uriarte. 2015. Tropical reforestation and climate change: beyond carbon. Restoration Ecology 23:337-343. http://dx.doi. org/10.1111/rec.12209

Locatelli, B., S. Lavorel, S. Sloan, U. Tappeiner, and D. Geneletti. 2017. Characteristic trajectories of ecosystem services in mountains. Frontiers in Ecology and the Environment 15:150-159. http://dx.doi.org/10.1002/fee.1470

Lugo, A. E. 1997. The apparent paradox of reestablishing species richness on degraded lands with tree monocultures. Forest Ecology and Management 99:9-19. http://dx.doi.org/10.1016/ $\underline{\text { S0378-1127(97)00191-6 }}$ 
Lugo, A. E. 2009. The emerging era of novel tropical forests. Biotropica 41:589-591. http://dx.doi.org/10.1111/j.1744-7429.2009.00550. $\underline{\mathrm{x}}$

Lund, H. G. 2009. What is a degraded forest? White paper prepared for FAO. Forest Information Services, Gainesville.

MacDicken, K. G., P. Sola, J. E. Hall, C. Sabogal, M. Tadoum, and C. de Wasseige. 2015. Global progress toward sustainable forest management. Forest Ecology and Management 352:47-56. http://dx.doi.org/10.1016/j.foreco.2015.02.005

Martin, P. A., A. C. Newton, and J. M. Bullock. 2013. Carbon pools recover more quickly than plant biodiversity in tropical secondary forests. Proceedings of the Royal Society B: Biological Sciences 280:2013-2236. http://dx.doi.org/10.1098/rspb.2013.2236

Mather, A. S. 1992. The forest transition. Area 24:367-379.

Mather, A. S. 2007. Recent Asian forest transitions in relation to the forest-transition theory. International Forestry Review 9:491502. http://dx.doi.org/10.1505/ifor.9.1.491

Mayer, E. 2002. The articulated peasant: household economies in the Andes. Westview Press, Boulder, Colorado, USA.

McGroddy, M. E., A. M. Lerner, D. V. Burbano, L. C. Schneider, and T. K. Rudel. 2015. Carbon stocks in silvopastoral systems: a study from four communities in southeastern Ecuador. Biotropica 47:407-415. http://dx.doi.org/10.1111/btp.12225

McLennan, B., and T. Garvin. 2012. Intra-regional variation in land use and livelihood change during a forest transition in Costa Rica's dry north west. Land Use Policy 29:119-130. http://dx.doi. org/10.1016/j.landusepol.2011.05.011

McNeely, J. A., and G. Schroth. 2006. Agroforestry and biodiversity conservation - traditional practices, present dynamics, and lessons for the future. Biodiversity \& Conservation 15:549554. http://dx.doi.org/10.1007/s10531-005-2087-3

Meyfroidt, P., and E. F. Lambin. 2008. The causes of the reforestation in Vietnam. Land Use Policy 25(2):182-197. http:// dx.doi.org/10.1016/j.landusepol.2007.06.001

Meyfroidt, P., and E. F. Lambin. 2011. Global forest transition: prospects for an end to deforestation. Annual Review of Environment and Resources 36:343-371. http://dx.doi.org/10.1146/ annurev-environ-090710-143732

Miettinen, J., and S. C. Liew. 2010. Degradation and development of peatlands in Peninsular Malaysia and in the islands of Sumatra and Borneo since 1990. Land Degradation \& Development 21:285296. http://dx.doi.org/10.1002/ldr.976

Montagnini, F., and P. K. R. Nair. 2004. Carbon sequestration: an underexploited environmental benefit of agroforestry systems. Agroforestry Systems 61:281-295. http://dx.doi.org/10.1007/978$-94-017-2424-120$

Morera, C., M. Romero, D. Avendaño, and A. Zúñigav. 2007. Evaluación de la conectividad entre Parque Nacional Piedras Blancas y la Fila de Cal. Pages 105-117 in O. Chassot y Carlos Morera, editor. Corredores Biológicos: Acercamiento Conceptual y Experiencias en América. Centro Científico Tropical/ Universidad Nacional de Costa Rica, San José, Costa Rica.
Mortimore, M. J., and W. M. Adams. 2001. Farmer adaptation, change and 'crisis' in the Sahel. Global Environmental Change 11:49-57. http://dx.doi.org/10.1016/S0959-3780(00)00044-3

Mortimore, M., and B. Turner. 2005. Does the Sahelian smallholder's management of woodland, farm trees, rangeland support the hypothesis of human-induced desertification? Journal of Arid Environments 63:567-595. http://dx.doi. org/10.1016/j.jaridenv.2005.03.005

Mulligan, M. 2010. Modeling the tropics-wide extent and distribution of cloud forest and cloud forest loss, with implications for conservation priority. Pages 14-38 in L. A. Bruijnzeel, F. N. Scatena, and L. S. Hamilton, editors. Tropical montane cloud forests: science for conservation and management. Cambridge University Press, Cambridge. http://dx.doi. org/10.1017/CBO9780511778384.004

Nabuurs, G. J., A. Pussinen, J. van Brusselen, and M. J. Schelhaas. 2007. Future harvesting pressure on European forests. European Journal of Forest Research 126:391-400. http://dx.doi. org/10.1007/s10342-006-0158-y

Nair, P. K. R., and D. Garrity. 2012. Agroforestry - the future of global land use. Springer, Dordrecht, Netherlands. http://dx.doi. org/10.1007/978-94-007-4676-3

Nanni, A. S., and H. R. Grau. 2014. Agricultural adjustment, population dynamics and forest redistribution in a subtropical watershed of northwest Argentina. Regional Environmental Change 14:1641-1649. http://dx.doi.org/10.1007/s10113-014-0608$\underline{\mathrm{X}}$

Norden, N., H. A. Angarita, F. Bongers, M. Martínez-Ramos, I. Granzow-de la Cerda, M. van Breugel, E. Lebrija-Trejos, J. A. Meave, J. Vandermeer, and G. B. Williamson. 2015. Successional dynamics in Neotropical forests are as uncertain as they are predictable. Proceedings of the National Academy of Sciences of the United States of America 112:8013-8018. http://dx.doi. org/10.1073/pnas.1500403112

Oliver, C. D., N. T. Nassar, B. R. Lippke, and B. J. McCarter. 2014. Carbon, fossil fuel, and biodiversity mitigation with wood and forests. Journal of Sustainable Forestry 33:248-275. http://dx.doi. org/10.1080/10549811.2013.839386

O'Loughlin, E., and E. K. S. Nambiar. 2001. Plantations, farm forestry and water. A report for the RIRDC/LWA/FWPRDC. Joint Venture Agroforestry Program. Publication No. 01/137. Rural Industries Research and Development Corporation.

Olsson, L. 2012. Greening of the Sahel. The Encyclopedia of Earth.

Olsson, L., L. Eklundh, and J. Ardö. 2005. A recent greening of the Sahel-trends, patterns and potential causes. Journal of Arid Environments 63:556-566. http://dx.doi.org/10.1016/j.jaridenv.2005.03.008

Padoch, C. 2007. The urbanizing Amazon: configuring resource use and transforming landscapes. Annual meeting of the Association for Tropical Biology and Conservation, Morelia, Michoacan, Mexico, July 15-19.

Padoch, C., E. Brondizio, S. Costa, M. Pinedo-Vesquez, R. R. Sears, and A. Siqueira. 2008. Urban forest and rural cities: multisited households, consumption patterns, and forest resources in 
Amazonia. Ecology and Society 13(2):2. http://dx.doi. org/10.5751/ES-02526-130202

Pascarella, J. B., T. M. Aide, M. I. Serrano, and J. K. Zimmerman. 2000. Land-use history and forest regeneration in the Cayey Mountains, Puerto Rico. Ecosystems 3:217-228. http://dx.doi. org/10.1007/s100210000021

Paviolo, A., C. De Angelo, Y. Di Blanco, and M. Di Bitetti. 2008. Jaguar Panthera onca population decline in the Upper Paraná Atlantic Forest of Argentina and Brazil. Oryx 42:554-561. http:// dx.doi.org/10.1017/S0030605308000641

Payn, T., J. M. Carnus, P. Freer-Smith, M. Kimberley, W. Kollert, S. Liu, C. Orazio, L. Rodriguez, L. N. Silva, and M. J. Wingfield. Changes in planted forests and future global implications. Forest Ecology and Management 352:57-67.

Perfecto, I., A. R. Robert, G. Russell, and M. E. van der Voort. 1996. Shade coffee: a disappearing refuge for biodiversity: shade coffee plantations contain as much biodiversity as forest habitats. BioScience 46(8):598-608. http://dx.doi.org/10.2307/1312989

Perz, S. G. 2007. Grand theory and context-specificity in the study of forest dynamics: forest transition theory and other directions. Professional Geographer 59:105-114. http://dx.doi.org/10.1111/ j.1467-9272.2007.00594.X

Phalan, B., M. Onial, A. Balmford, and R. E. Green. 2011. Reconciling food production and biodiversity conservation: land sharing and land sparing compared. Science 333:1289-1291. http://dx.doi.org/10.1126/science.1208742

Piotto, D., D. Craven, F. Montagnini, and F. Alice. 2010. Silvicultural and economic aspects of pure and mixed native tree species plantations on degraded pasturelands in humid Costa Rica. New Forests 39:369-385. http://dx.doi.org/10.1007/ $\underline{\text { s11056-009-9177-0 }}$

Piotto, D., E. Víquez, F. Montagnini, and M. Kanninen. 2004. Pure and mixed forest plantations with native species of the dry tropics of Costa Rica: a comparison of growth and productivity. Forest Ecology and Management 190:359-372. http://dx.doi. org/10.1016/j.foreco.2003.11.005

Poorter, L., F. Bongers, T. M. Aide, A. M. A. Zambrano, P. Balvanera, J. M. Becknell, V. Boukili, P. H.Brancalion, E. N. Broadbent, R. L. Chazdon, and D. Craven. 2016. Biomass resilience of Neotropical secondary forests. Nature 530:211-214. http://dx.doi.org/10.1038/nature16512

Potvin, C., L. Mancilla, N. Buchmann, J. Monteza, T. Moore, M. Murphy, Y. Oelmann, M. Scherer-Lorenzen, B. J. Turner, W. Wilcke, F. Zeugin, and S. Wolf. 2011. An ecosystem approach to biodiversity effects: carbon pools in a tropical tree plantation. Forest Ecology and Management 261:1614-1624. http://dx.doi. org/10.1016/j.foreco.2010.11.015

Power, A. G. 2010. Ecosystem services and agriculture: tradeoffs and synergies. Philosophical Transactions of the Royal Society B: Biological Sciences 365:2959-2971. http://dx.doi.org/10.1098/ $\underline{\text { rstb. } 2010.0143}$

Putz, F. E., and C. Romero. 2014. Futures of tropical forests (sensu lato). Biotropica 46:495-505. http://dx.doi.org/10.1111/btp.12124
Rasmussen, K., B. Fog, and J. E. Madsen. 2001. Desertification in reverse? observations from northern Burkina Faso. Global Environmental Change 11:271-282. http://dx.doi.org/10.1016/ S0959-3780(01)00005-X

Redman, C., and D. R. Foster. 2008. Agrarian landscapes in transition: comparisons of long-term ecological and cultural change. Oxford University Press, Oxford, UK.

Redo, D. J., H. R. Grau, T. M. Aide, and M. L. Clark. 2012. Asymmetric forest transition driven by the interaction of socioeconomic development and environmental heterogeneity in Central America. Proceedings of the National Academy of Sciences of the United States of America 109(23):8839-8844. http://dx.doi.org/10.1073/pnas.1201664109

Reij, C. 2006. More success stories in Africa's drylands than often assumed. Conference proceedings of the Forum sur la Souveraineté Alimentaire, Niamey, Niger, Nov. 7-10. Reseau des Organisations Paysannes et de Producteurs Agricoles de L'Afrique de L'Ouest, Niamey, Niger.

Reij, C., G. Tappan, and A. Belemvire. 2005. Changing land management practices and vegetation on the Central Plateau of Burkina Faso (1968-2002). Journal of Arid Environments 63:642659. http://dx.doi.org/10.1016/j.jaridenv.2005.03.010

Reij, C., and A. Waters-Bayer, editors. 2014. Farmer innovation in Africa: a source of inspiration for agricultural development. Routledge.

Robbins, P., and A. Fraser. 2003. A forest of contradictions: producing the landscapes of the Scottish Highlands. Antipode 35 (1):95-118. http://dx.doi.org/10.1111/1467-8330.00304

Rudel, T. K. 2005. Tropical forests: regional paths of destruction andregeneration in the late twentieth century. Columbia University Press, New York, New York, USA. http://dx.doi.org/10.7312/ $\underline{\text { rude13194 }}$

Rudel, T. K. 2009. Three paths to forest expansion: a comparative historical analysis. Pages 45-57 in $\mathrm{H}$. Nagendra, and $\mathrm{J}$. Southworth, editors. Reforesting landscapes linking pattern and process. Springer, Dordrecht, Netherlands. http://dx.doi. org/10.1007/978-1-4020-9656-3 3

Rudel, T. K. 2012. The human ecology of regrowth in the tropics. Journal of Sustainable Forestry 31:340-354. http://dx.doi. org/10.1080/10549811.2011.588457

Rudel, T. K., D. Bates, and R. Machinguiashi. 2002. A tropical forest transition? Agricultural change, out-migration, and secondary forests in the Ecuadorian Amazon. Annals of the Association of American Geographers 92(1):87-102. http://dx.doi. org/10.1111/1467-8306.00281

Rudel, T. K., O. T. Coomes, E. Moran, F. Achard, A. Angelsen, J. Xu, and E. Lambin. 2005. Forest transitions: towards a global understanding of land use change. Global Environmental Change 15:23-31. http://dx.doi.org/10.1016/j.gloenvcha.2004.11.001

Rudel, T. K., S. Sloan, R. Chazdon, and R. Grau. 2016. The drivers of tree cover expansion: global, temperate, and tropical zone analyses. Land Use Policy 58:502-513. http://dx.doi. org/10.1016/i.landusepol.2016.08.024 
Sarmiento, F. O. 2002. Anthropogenic change in the landscapes of highland Ecuador. Geographical Review 92:213-234. http://dx. doi.org/10.2307/4140971

Schelhas, J., and M. J. Pfeffer. 2008. Saving forests, protecting people? Environmental conservation in Central America. AltaMira Press, Walnut Creek, California, USA.

Schmook, B., and C. Radel. 2008. International labor migration from a tropical development frontier: globalizing households and an incipient forest transition. Human Ecology 36:891-908. http:// dx.doi.org/10.1007/s10745-008-9207-0

Schroth, G., and C. A. Harvey. 2007. Biodiversity conservation in cocoa production landscapes: an overview. Biodiversity and Conservation 16:2237-2244. http://dx.doi.org/10.1007/s10531-007-9195-1

Schroth, G., C. A. Harvey, and G. Vincent. 2004. Complex agroforests: their structure, diversity, and potential role in landscape conservation. Pages 227-260 in G. Schroth, G. A. B. da Fonseca, C. A. Harvey, C. Gascon, H. L. Vasconcelos, and A. N. Izac, editors. Agroforestry and biodiversity conservation in tropical landscapes. Island Press, Washington, D.C., USA.

Seaquist, J., T. Hickler, L. Eklundh, J. Ardö, and B. Heumann. 2009. Disentangling the effects of climate and people on Sahel vegetation dynamics. Biogeosciences 6:469-477. http://dx.doi. org/10.5194/bg-6-469-2009

Sloan, S. 2008. Reforestation amidst deforestation: simultaneity and succession. Global Environmental Change 18:425-441. http:// dx.doi.org/10.1016/j.gloenvcha.2008.04.009

Sloan, S. 2015. The development-driven forest transition and its utility for REDD+. Ecological Economics 116:1-11. http://dx.doi. org/10.1016/j.ecolecon.2015.04.010

Sloan, S. 2016. Tropical forest expansion and interactions amongst agents of forest change. Forests 16(55).

Sloan, S., M. Goosem, and S. G. Laurance. 2015. Tropical forest regeneration following land abandonment is driven by primary rainforest distribution in old pastoral region. Landscape Ecology 31:601-618. http://dx.doi.org/10.1007/s10980-015-0267-4

Sloan, S., and J. A. Sayer. 2015. Forest Resources Assessment of 2015 shows positive global trends but forest loss and degradation persist in poor tropical countries. Forest Ecology and Management 352:134-145. http://dx.doi.org/10.1016/j.foreco.2015.06.013

Sonter, L. J., D. J. Barret, B. S. Soares-Filho, and C. J. Moran. 2014. Global demand for steel drives extensive land-use change in Brazil's Iron Quadrangle. Global Environmental Change 26:6372. http://dx.doi.org/10.1016/j.gloenvcha.2014.03.014

Stern, D. I. 2004. The rise and fall of the environmental Kuznets curve. World Development 32(8):1419-1439. http://dx.doi. org/10.1016/j.worlddev.2004.03.004

Styger, E., H. M. Rakotondramasy, M. J. Pfeffer, E. Fernandes, and D. M. Bates. 2007. Influence of slash-and-burn farming practices on fallow succession and land degradation in the rainforest region of Madagascar. Agriculture, Ecosystems \& Environment 119:257-269. http://dx.doi.org/10.1016/j.agee.2006.07.012

Tiffen, M, M. Mortimore, and F. Gichuki. 1994. More people, less erosion: environmental recovery in Kenya. John Wiley and Sons, New York, New York, USA.
Thomlinson, J. R., M. I. Serrano, T. M. Lopez, T. M. Aide, and J. K. Zimmerman. 1996. Land-use dynamics in a post-agricultural Puerto Rican landscape (1936-1988). Biotropica 28:525-536. http://dx.doi.org/10.2307/2389094

Tropek, R., O. Sedláček, J. Beck, P. Keil, Z. Musilová, I. Šímová, and D. Storch. 2014. Comment on "High-resolution global maps of 21st-century forest cover change". Science 344:981. http://dx. doi.org/10.1126/science. 1248753

Tscharntke, T., Y. Clough, T. C. Wanger, L. Jackson, I. Motzke, I. Perfecto, J. Vandermeer, and A. Whitbread. 2012. Global food security, biodiversity conservation and the future of agricultural intensification. Biological Conservation 151:53-59. http://dx.doi. org/10.1016/j.biocon.2012.01.068

Uhl, C., R. Buschbacher, and E. Serrao. 1988. Abandoned pastures in eastern Amazonia. I. Patterns of plant succession. Journal of Ecology 76:663-681. http://dx.doi.org/10.2307/2260566

Vaca, R. A., D. J. Golicher, L. Cayuela, J. Hewson, and M. Steininger. 2012. Evidence of incipient forest transition in southern Mexico. PLoS ONE 7(8):e42309. http://dx.doi. org/10.1371/journal.pone.0042309

Vallet, A., B. Locatelli, H. Levrel, C. B. Pérez, P. Imbach, N. E. Carmona, R. Manlay, and J. Oszwald. 2016. Dynamics of ecosystem services during forest transitions in Reventazón, Costa Rica. PloS ONE 11:e0158615. http://dx.doi.org/10.1371/journal. pone. 0158615

Waters, W. F. 1997. The road of many returns: rural bases for the informal urban economy in Ecuador. Latin American Perspectives 24:50-64. http://dx.doi.org/10.1177/0094582X9702400304

Wilson, S. J. 2015. Replanting a future: restoring cloud forests, biodiversity, and rural livelihoods in Andean landscapes. Dissertation. McGill University, Montreal, Quebec, Canada.

Wilson, S. J., and J. M. Rhemtulla. 2016. Acceleration and novelty: community restoration speeds recovery and transforms species composition in Andean cloud forest. Ecological Applications 26:203-218. http://dx.doi.org/10.1890/14-2129

Young, K. R. 2011. Introduction to Andean geographies. Pages 128-140 in S. K. Herzog, R. Martínez, P. M. Jørgensen, and H. Tiessen, editors. Climate change and biodiversity in the tropical Andes. Inter-American Institute for Global Change Research.

Zhang, D., J. Zhang, W. Yang, and F. Wu. 2010. Potential allelopathic effect of Eucalyptus grandis across a range of plantation ages. Ecological Research 25:13-23. http://dx.doi. org/10.1007/s11284-009-0627-0

Zurita, G. A., N. Rey, D. M. Varela, M. Villagra, and M. I. Bellocq. 2006. Conversion of the Atlantic Forest into native and exotic tree plantations: effects on bird communities from the local and regional perspectives. Forest Ecology and Management 235:164 173. http://dx.doi.org/10.1016/j.foreco.2006.08.009 
Appendix 1. Categorizing countries by forest transition (FT) type.

The aim of this analysis was to provide and pilot a framework for evaluating the ecological impacts of forest transitions, which will become more useful as remote sensing technology improves our ability to distinguish between different types of secondary forest. To understand where different types of transitions are occurring, and the relative scales at which different packages of ecosystem services are unfolding globally, we classified countries with high levels of reforestation (Figure 2) according to their apparent predominant forest transition type. First, we used satellite estimates from the Hansen dataset (Hansen et al. 2013) to select the 50 countries with the greatest national proportional gross forest cover gain between 2000 and 2012. These 50 countries included all continents (except Antarctica) and several biomes (Table 1). We then categorized each as undergoing either a forest plantation transition, an agro-forestry transition, or a spontaneous regeneration transition. Because a number of countries had a relatively even distribution of two or more forest types, we added a "mixed" forest transition category with an even combination of plantations, agro-forestry or spontaneous regrowth. Countries were group into one of these four types as follows: A national "forest plantation transition" occurred where more than $>50 \%$ of the gross forest cover gain according to Hansen et al. (2013) was attributed to an increase in planted forest area from 2000-2010 according the FAO FRA 2010 (FAO, 2010). Planted forests range from monotypic industrial plantations to seminatural forests propagated by assisted reforestation (FAO, 2010). An "agroforestry transition" occurred where $>50 \%$ of gross forest cover gain according to Hansen et al. (2013) occurred within "agricultural" and "agricultural mosaic" lands of 2001 as mapped by the MODIS MCD12Q1 global-land cover classification (Friedl et al. 2010), following the approach of Zomer et al. (2014). The label of "spontaneous regeneration transition" was applied to any country not satisfying these criteria for a forest-plantation or agro-forestry FT. In general, the spontaneous forest transition label describes natural forest gain dispersed in large part outside agricultural landscapes. The label of "mixed" forest transition was applied where forest cover was evenly split between two or more types of cover

In the absence of better global data, agroforestry was necessary defined here simply as an increase in forest cover on agricultural lands, as per Zomer et al. (2014). In practice, it is ambiguous whether the agroforest extent thus calculated comprises forests and fallows managed for agriculture (i.e., agroforestry) on still-occupied agricultural lands, or by natural regrowth on 
abandoned agricultural lands. In the latter case, this would mean our agroforestry classification would be conflated with a spontaneous regeneration transition in contexts of widespread agricultural abandonment (Rudel et al. 2000). This data limitation speaks to the need for a comprehensive global database of agroforestry, which at present time does not exist. Our estimation here represents an alternative used elsewhere in the literature (Zomer et al. 2014). 